Original Research

\title{
Characteristics, Sources and Risk Assessment of Heavy Metals in the Ganjiang River Basin, China
}

\author{
Wang Shu ${ }^{1,2}$, Peng Wang, ${ }^{1,}$, Jun Zhao ${ }^{1,2}$, Xiaofang Yu ${ }^{1,2}$, Qiyu Xu ${ }^{1,2}$ \\ ${ }^{1}$ School of Geography and Environment, Jiangxi Normal University, Nanchang, Jiangxi, China \\ ${ }^{2}$ Key Laboratory of Poyang Lake Wetland and Watershed Research, Ministry of Education, \\ Jiangxi Normal University, Nanchang, Jiangxi, China
}

Received: 17 February 2019

Accepted: 4 June 2019

\begin{abstract}
Heavy metal pollution is one of the important threats to river water quality and human health. Here, we collected surface water samples from the mainstream and tributaries in the Ganjiang River basin in January and July, 2015, in order to delineate the temporal-spatial distribution characteristics of heavy metals, identify their sources, and assess their potential risk. Compared with China's environmental quality standards for drinking water, our results revealed that 5 heavy metals, including $\mathrm{Fe}, \mathrm{Al}, \mathrm{As}, \mathrm{Mn}$ and $\mathrm{Tl}$, exceeded the standard values and the over-standard rates were $21.62 \%, 16.22 \%, 8.11 \%, 4.05 \%$ and $4.05 \%$, respectively. The concentrations of hydrochemical ions and heavy metals exhibited significant seasonal variation and spatial heterogeneity. Multivariate statistical approaches indicated that intense anthropogenic activities (mining industries and agricultural activities) were the most important sources of heavy metals in the Ganjiang River, and the upstream of the Ganjiang (in southern Jiangxi Province) and the Yuan River were the regions with the most serious pollution. Assessming health risk using the hazard index (HI) and carcinogenic risk (CR) recommended by the USEPA showed that children were more susceptible to the health risk than adults, and As was the most largest contributor leading to noncarcinogenic and carcinogenic risk to human health. Therefore, effective measures such as controls on mining wastewater and the use of pesticides and fertilizers should be taken by local government to protect aquatic ecosystems and human health.
\end{abstract}

Keywords: heavy metals, distribution characteristics, source identification, health risk assessment, Ganjiang River basin

*e-mail: wangpengjlu@jxnu.edu.cn 


\section{Introduction}

River water is one of the most important sources of drinking water for humans, and its quality is vital to human health $[1,2]$. However, as a result of rapid industrialization and urban expansion, lots of pollutants are discharged into rivers, causing severe deterioration of river water quality [3, 4]. Heavy metal pollution, as one of the most important threats, has aroused wide attention due to its toxicity, irreversibility and persistence [4-6]. Therefore, it is necessary to analyze the sources of heavy metal pollution and assess the potential health risks to better manage and protect water resources.

Numerous studies have shown that heavy metals are derived from different natural processes, such as bedrock weathering, soil erosion and atmospheric deposition, and intensive anthropogenic activities such as agricultural runoff, domestic sewage and mineral processing [7-9]. But the sources of heavy metals are inconsistent due to differences in regional natural environments and anthropogenic activities [10, 11]. Fortunately, multivariate statistical analysis approaches, which provide reliable means to interpret the potential heavy metal pollution sources and describe water interaction dynamics, have been widely employed in geochemical and hydrochemical pollution research $[4,12,13]$. For example, Keefe et al. [13] used those techniques to characterize the sources of pollution in three water bodies, including municipal effluent, surface water and groundwater. Varol et al. [14] found that intensive anthropogenic activities, particularly the discharge of effluents from copper mines, were responsible for heavy metal pollution in the Tigris River.

When heavy metal pollution is discharged into the river, they tend to gradually accumulate at the bottom of the river. Subsequently, sediment heavy metals will be re-released into the surface water due to environmental changes, such as sediment resuspension, reductionoxidation reaction, etc., which will increase the heavy metals concentrations [15]. Additionally, heavy metals are gradually absorbed and biomagnified in food chains, threatening aquatic life and human health [16]. Numerous studies have reported that excessive pollution would cause hypertension, vascular disease, restrictive lung disease and other organ damage $[6,17,18]$. Given the current unfavorable situation, several powerful methods, including human health risk assessment models, heavy metal pollution index (HPI), water quality index (WQI) and entropy water quality index (EWQI) have been proposed and used to evaluate the risk of heavy metal pollution [2, 4, 6, 19]. Using HPI, Rakotondrabe et al. [12] found that the value of pollution index was larger than the acceptable value and the water quality of the Mari River was poor. Similarly, Ahmed et al. [18] showed that As had higher hazard quotient values than other elements, and children were more likely to be subjected to non-carcinogenic and carcinogenic risks than adults in Surma basin.
Ganjiang River, the largest river in Poyang Lake basin, plays an important role in providing drinking water, irrigation and fishery services for the local residents [20]. The Ganjiang River basin feeds more than 20.2 million people, and the pollution of the basin has become increasingly prominent with the acceleration of industrialization and agriculturalization processes in the past decade [21, 22]. Hu et al. [23] found that mining activities and industrial activities caused severe heavy metal pollution in the river. Moreover, Zhang et al. [24] demonstrated that local residents were susceptible to non-carcinogenic and carcinogenic risks caused by heavy metal pollution, and As was the primarily pollutant-causing risk. Nevertheless, the existing research has focused on several mainstream sites or certain river sections. There is less information about the heavy metals pollution in the whole Ganjiang River basin, which could not systematically reflect the pollution levels and sources of heavy metals. Some studies have shown that hydrochemical ions are closely related to heavy metals and can serve as important pollution indicators [2, 12]. Several studies have explored the associations between heavy metals and land use patterns or bacterial communities of the Ganjiang River basin [25, 26]. To our knowledge, there is still a lack of combined analysis of hydrochemical ions and heavy metals to explore water pollution of the Ganjiang River.

Here, we collected surface water samples from mainstream and tributaries of the Ganjiang River in January and July 2015. We aimed to delineate spatial and temporal variation characteristics of heavy metals and major hydrochemistry ions, to identify the potential pollution sources of heavy metals, and to assess their potential risk for resident drinking water. This research was expected to provide important insight into studying heavy metal pollution and watershed ecosystem protection.

\section{Materials and Methods}

\section{Study Area}

The Ganjiang River basin is the largest subbasin of Poyang Lake basin, covering an area of $8.28 \times 10^{4} \mathrm{~km}^{2}, 98.45 \%$ of which belongs to Jiangxi Province (Fig. 1). In the study, the total length of the main river channel is approximately $823 \mathrm{~km}$. Controlled by the typical subtropical monsoon climate, the annual average temperature in the region is $18.3^{\circ} \mathrm{C}$, with the hottest and coldest months being July and January, respectively. The average annual precipitation is around $1,580 \mathrm{~mm}$, and heavy rainfall occurs from March to August, accounting for $72.8 \%$ of the annual precipitation.

Geologically, the study area is located on the southeastern edge of the Eurasian plate. The north and south are divided into the Yangtze block and the 
Huaxia block. Magmatic activities are frequent in the basin, and magmatic rocks are widely distributed. The most widely exposed aquifers in this area are weakly water-rich magmatic rocks, metamorphic rocks, general clastic rock type aquifers, pore fissure aquifers, residual slopes, and alluvial deposits covering an area of $1.40 \times 10^{5} \mathrm{~km}^{2}$, accounting for $83.2 \%$ of the province's total area. Strong and rich water-rich carbonate karst aquifers and alluvial, lake sediment loose rock pore aquifers, with an area of $2.7 \times 10^{4} \mathrm{~km}^{2}$, account for $16 \%$ of the province's area. The hydrogeological map of the study area can be obtained from the following website: http://www.ngac.org.cn/Document/Map.aspx? MapId=EC7E1A7A79181954E0430100007F182E. The southern part of the Ganjiang River basin (southern Jiangxi Province) is abundant in tungsten ore and the output accounts for nearly a half in China [27, 28], while Chinese output accounted for $82 \%$ of the global totals [29]. Apart from tungsten, the study area is also abundant in $\mathrm{Mn}, \mathrm{Fe}, \mathrm{Sn}, \mathrm{V}, \mathrm{U}$ and coal mines.

\section{Sample Collection}

Two water sample surveys were conducted from the river in 37 sites along the Ganjiang River basin from its origin to mouth during dry (January 2015) and wet (July 2015) seasons (Fig. 1). Among the 37 sampling sites,

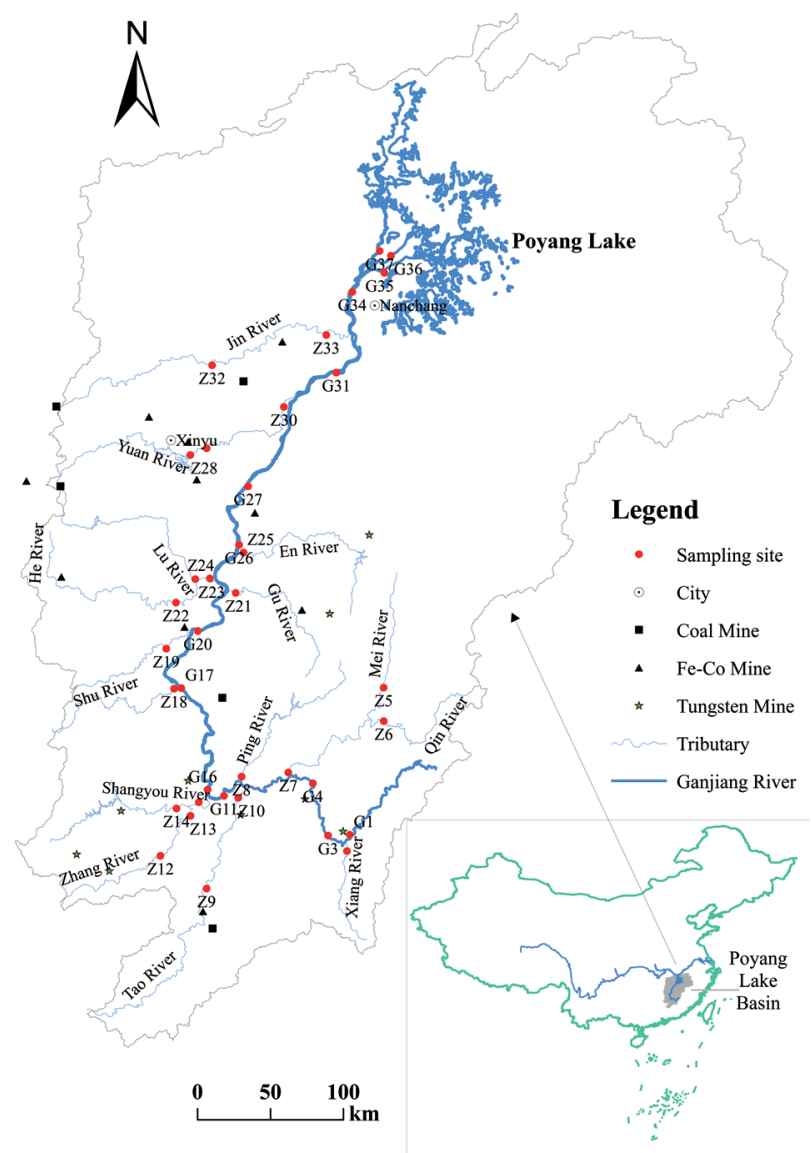

Fig. 1. Study area and sampling sites in the Ganjiang River basin.
14 sites were along the mainstream, and the other were on the major tributaries. Water samples were collected from a depth of approximately $50 \mathrm{~cm}$ in the center of the river channel and filtered through $0.45 \mu \mathrm{m}$ Millipore nitrocellulose filter. During sample collection, electrical conductivity (EC) was determined using a HI 98360 probe (Hanna Instruments Ltd., Italy) and HCO3- was measured by titration, which were listed in Table 1 . About $25 \mathrm{~mL}$ filtrate was acidified to $\mathrm{pH}<2$ with ultrapurified $\mathrm{HNO}_{3}$ in pre-cleaned high-density polyethylene bottles for metal analysis, and the remaining samples were placed into a polypropylene sampling bottles for determining hydrochemical ions. All samples were stored in a refrigerator at $4^{\circ} \mathrm{C}$ in the dark until analysis.

The concentrations of major cations, including $\mathrm{Na}^{+}$, $\mathrm{K}^{+}, \mathrm{Mg}^{2+}$ and $\mathrm{Ca}^{2+}$, were measured by a plasma emission spectrometer (Optima 8000, PerkinElmer, USA) and major anions including $\mathrm{Cl}^{-}$and $\mathrm{SO}^{2-}$ were determined by ion chromatograph (ICP-90, Dionex, USA). The results of recovery percentage were between $95-100 \%$ with $2 \%$ standard deviation, and the charge balances of those cations and anions were less than $10 \%$ - verifying the precision of the measurement. The concentrations of 16 elements, including $\mathrm{Al}, \mathrm{Tl}, \mathrm{V}, \mathrm{Cr}, \mathrm{Mn}, \mathrm{Fe}, \mathrm{Pb}, \mathrm{Co}$, $\mathrm{Ni}, \mathrm{Cu}, \mathrm{Zn}, \mathrm{As}, \mathrm{Mo}, \mathrm{Cd}, \mathrm{Sb}$ and $\mathrm{U}$ were determined using ICP-MS (Thermo X series II, USA). The accuracy and precision of the methods and results were checked by using the certified Standard Reference Materials (SRM-1640 and SRM-1643e of National Institute of Scientific \& Technology, USA). The detection limits were $0.065(\mathrm{Al}), 0.04(\mathrm{~V}), 0.019(\mathrm{Cr}), 0.011(\mathrm{Mn})$, $1.929(\mathrm{Fe}), 0.005(\mathrm{Co}), 0.044(\mathrm{Ni}), 0.042(\mathrm{Cu}), 0.027$ (Zn), 0.094 (As), 0.003 (Mo), 0.001 (Cd), 0.004 (Sb), $0.004(\mathrm{Tl}), 0.002(\mathrm{~Pb})$ and $0.001(\mathrm{U})$. Recovery rates of the above elements spiked in water ranged from $89 \%$ to $110 \%$. The reagents and procedural blanks were examined in parallel using the same procedure as the sample processing. Each calibration curve was estimated by determining quality control criteria before, during, and after a set of sample measurements. The relative standard deviation (RSD) of all two-time parallel samples for all elements was less than $10 \%$.

\section{Data Statistical Methods}

\section{Multivariate Statistical Approaches}

Multivariate statistical approaches, such as factor/ principal component analysis (FA/PCA), correlation analysis, hierarchical cluster analysis (HCA) and analysis of variance (ANOVA), which can interpret underlying structures between variables and reduce dimensionality of complex datasets without much information loss, have been broadly applied to environmental pollution research $[4,12,30]$. In this study, sampling sites were grouped by HCA (Ward method) based on heavy metal data to analyse the spatial difference. ANOVA was used to test whether there were significant differences in hydrochemical parameters between different 
seasons (dry season and wet season) and different zones clustered by HCA $(p<0.05$, least-significance difference, LSD). Pearson's correlation heatmap was used to demonstrate associations between the selected parameters. FA/PCA (Varimax Kaiser Normalization) was conducted to identify major pollution sources, and those PCs with eigenvalue $>1$ were retained. Detailed statistical analysis procedures were shown in $\mathrm{Bu}$ et al. [31], and all statistical analyses were performed by SPSS 24.0 and Origin 2018 for Windows software packages.

\section{Heavy Metal Pollution Index (HPI)}

Heavy metal pollution index (HPI) was used to evaluate the combined effects of each heavy metal on the total quality of water [32]. The method assigns a respective weightage value (Wi) to each metal on which the index is based. The weightage value (Wi) is any value between 0 and 1 , which reflects the relative importance of each metal. It can be defined as inversely proportional to the recommended standard ( $\mathrm{Si}$ ) for each parameter. In the present study, the maximum permissible value $(\mathrm{Si})$ for each metal is taken from drinking water quality standard [33, 34]. The HPI model is proposed by Mohan [35]. If the HPI is below 100, the overall condition of the water body is considered to be at an acceptable level for an aquatic ecosystem [12].

$$
\mathrm{HPI}=\frac{\sum_{i=1}^{n} W i \cdot Q i}{\sum_{i=1}^{n} W i}
$$

...where Wi is the united weightage of ith parameters, Qi is the sub index of the ith parameter, and $\mathrm{n}$ is the number of parameters considered.

$$
Q i=100 \times V i / S i
$$

...where $\mathrm{Vi}$ and $\mathrm{Si}$ are the monitored concentrations in $\mu \mathrm{g} / \mathrm{L}$ and the maximum permissible value of the ith corresponding metal, respectively.

\section{Human Health Risk Assessment}

Heavy metals pose a carcinogenic and noncarcinogenic risk to human health through two of the most common exposure pathways, including ingestion and skin absorption (excluding inhalation via the mouth and nose) [10]. The doses through oral intake and dermal pathways are calculated by Eqs. (1) and (2) respectively as below:

$$
\begin{gathered}
A D D_{\text {ingestion }}=\frac{C_{w} \times I R \times A B S_{G I} \times E F \times E D}{B W \times A T} \\
A D D_{\text {dermal }}=\frac{C_{W} \times K_{p} \times S A \times E D \times E F \times E T \times C F}{B W \times A T}
\end{gathered}
$$

...where $\mathrm{ADD}_{\text {ingestion }}$ and $\mathrm{ADD}_{\text {dermal }}$ refer to the average daily doses from ingestion and dermal absorption respectively, and unit in $\mu \mathrm{g} /(\mathrm{kg} \cdot$ day $) ; \mathrm{C}_{\mathrm{w}}$, chemical concentration of heavy metals in each water sample, and are given as $\mu \mathrm{g} / \mathrm{L}$; IR, the ingestion rate $(1.5$ and $2.2 \mathrm{~L} /$ day for children and adults); $\mathrm{EF}$ is exposure frequency and equal to 350, and unit in days/year; ED, the exposure duration (6 and 30 years for children and adults, respectively); BW, the body weight (15 kg for children and $70 \mathrm{~kg}$ for adults); AT is averaging time (days); SA is exposed skin area $(6,600 \mathrm{~cm} 2$ for children and $18,000 \mathrm{~cm}^{2}$ for adults); ET is exposure time, unit in $\mathrm{h} / \mathrm{day}$; Kp, the dermal permeability coefficient in water $(\mathrm{cm} / \mathrm{h})$; and ABSGI refers to gastrointestinal absorption factor (dimensionless). The parameter values we referred to are mainly based on those proposed by the U.S. EPA [36], and some parameter values are supplemented and modified according to other references [4, 37].

Carcinogenic and non-carcinogenic risk can be quantified by calculating hazard quotient (HQ) and cancer risk (CR). HQ is evaluated by calculating the ratio of the ADD value of each exposure route (ingestion, skin) to the corresponding reference dose (RfD) to reflect the non-carcinogenic risk (Eq. (3)). When the value of $\mathrm{HQ}>1$, non-carcinogenic risks should be of concern. Total hazard index (HI), the sum of the HQs, is employed to evaluate the total potential noncarcinogenic risks, with $\mathrm{HI}>1$, indicating an adverse effect on human health (Eq. (5)). CR is calculated by Eq. (6), and the acceptable range is $10^{-6}$ to $10^{-4}$ [36].

$$
\begin{gathered}
\text { Hazard Quotient }(\mathrm{HQ})=\frac{A D D}{R f D} \\
R f D_{\text {dermal }}=\mathrm{RfD} \times A B C_{G I} \\
\mathrm{HI}=\sum_{i=1}^{n}\left(H Q_{\text {ingestion }}+H Q_{\text {dermal }}\right)
\end{gathered}
$$

Cancer Risk $(C R)=\mathrm{ADD} \times \mathrm{CSF}($ cancer slope factor $)$

Unless otherwise stated, the above models are obtained from U.S. Environmental Protection Agency documents (https://www.epa.gov/ground-water-anddrinking-water).

\section{Results}

\section{Temporal-Spatial Variation of Major Hydrochemical Ions}

The temporal-spatial variations of major hydrochemical ions from two seasons at the 37 sampling sites are shown in Fig. S1 and Table 1. ANOVA indicated little difference for each variable between mainstream and tributaries except for $\mathrm{Cl}^{-}$, whose average concentration in the mainstream was significantly higher than in tributaries $(\mathrm{p}=0.014)$. Hydrochemical ion concentrations (except for $\mathrm{NO}_{3}^{-}$) in the dry season were significantly higher than those in the wet season. 
Table 1. Descriptive statistics of hydrochemical ions in water samples from Ganjiang River basin.

\begin{tabular}{|c|c|c|c|c|c|c|c|c|c|c|c|}
\hline & & $\begin{array}{c}\text { EC } \\
(\mu \mathrm{S} / \mathrm{cm})\end{array}$ & $\begin{array}{l}\mathrm{HCO}_{3}^{-} \\
(\mathrm{mg} / \mathrm{L})\end{array}$ & $\begin{array}{c}\mathrm{Cl}^{-} \\
(\mathrm{mg} / \mathrm{L})\end{array}$ & $\begin{array}{c}\mathrm{SO}_{4}^{2-} \\
(\mathrm{mg} / \mathrm{L})\end{array}$ & $\begin{array}{c}\mathrm{Na}^{+} \\
(\mathrm{mg} / \mathrm{L})\end{array}$ & $\begin{array}{c}\mathrm{K}^{+} \\
(\mathrm{mg} / \mathrm{L})\end{array}$ & $\begin{array}{c}\mathrm{Mg}^{2+} \\
(\mathrm{mg} / \mathrm{L})\end{array}$ & $\begin{array}{c}\mathrm{Ca}^{2+} \\
(\mathrm{mg} / \mathrm{L})\end{array}$ & $\begin{array}{l}\mathrm{NH}_{4}^{+}-\mathrm{N} \\
(\mathrm{mg} / \mathrm{L})\end{array}$ & $\begin{array}{c}\mathrm{NO}_{3}^{-} \\
(\mathrm{mg} / \mathrm{L})\end{array}$ \\
\hline \multirow{4}{*}{$\begin{array}{l}\text { Dry season (n } \\
\quad=37)\end{array}$} & Min & 56.80 & 17.08 & 0.53 & 2.42 & 2.84 & 2.51 & 1.12 & 6.86 & 0.14 & 0.11 \\
\hline & Max & 241.00 & 106.55 & 57.96 & 34.29 & 44.07 & 5.48 & 6.45 & 43.06 & 1.54 & 4.26 \\
\hline & Mean & $127.94^{\mathrm{a}}$ & $51.81^{\mathrm{a}}$ & $12.64^{\mathrm{a}}$ & $15.31^{\mathrm{a}}$ & $12.78^{\mathrm{a}}$ & $3.80^{\mathrm{a}}$ & $3.36^{\mathrm{a}}$ & $19.18^{\mathrm{a}}$ & $0.54^{\mathrm{a}}$ & $0.75^{b}$ \\
\hline & S.D & 44.12 & 23.84 & 11.62 & 8.40 & 8.05 & 0.82 & 1.34 & 9.36 & 0.33 & 0.85 \\
\hline \multirow{4}{*}{$\begin{array}{l}\text { Wet season } \\
\qquad(\mathrm{n}=37)\end{array}$} & Min & 32.20 & 14.64 & 1.03 & 1.50 & 0.31 & 0.73 & 0.36 & 4.49 & 0.08 & 0.51 \\
\hline & Max & 157.20 & 87.23 & 27.66 & 28.98 & 18.30 & 3.37 & 4.25 & 33.92 & 0.53 & 18.88 \\
\hline & Mean & $72.63^{b}$ & $36.40^{\mathrm{b}}$ & $5.85^{\mathrm{b}}$ & $8.87^{b}$ & $4.10^{\mathrm{b}}$ & $1.99^{\mathrm{b}}$ & $1.71^{\mathrm{b}}$ & $11.87^{\mathrm{b}}$ & $0.25^{\mathrm{b}}$ & $3.29^{\mathrm{a}}$ \\
\hline & S.D & 30.56 & 18.36 & 5.33 & 5.95 & 3.14 & 0.66 & 1.06 & 6.93 & 0.11 & 3.76 \\
\hline \multirow{4}{*}{$\begin{array}{l}\text { Mainstream } \\
\quad(\mathrm{n}=14)\end{array}$} & Min & 48.50 & 20.13 & 2.57 & 4.57 & 1.75 & 1.42 & 0.57 & 6.30 & 0.10 & 0.29 \\
\hline & Max & 176.10 & 87.43 & 36.32 & 20.30 & 30.98 & 5.40 & 3.89 & 25.31 & 1.54 & 5.49 \\
\hline & Mean & 96.26 & 40.74 & $10.97^{\mathrm{a}}$ & 11.05 & 9.37 & 3.06 & 2.25 & 13.77 & 0.43 & 1.64 \\
\hline & S.D & 38.36 & 15.04 & 8.15 & 4.80 & 7.24 & 1.12 & 1.01 & 4.80 & 0.32 & 1.35 \\
\hline \multirow{4}{*}{$\begin{array}{l}\text { Tributary } \\
(n=23)\end{array}$} & Min & 32.20 & 14.64 & 0.53 & 1.50 & 0.31 & 0.73 & 0.36 & 4.49 & 0.08 & 0.11 \\
\hline & Max & 241.00 & 106.55 & 57.96 & 34.29 & 44.07 & 5.48 & 6.45 & 43.06 & 1.49 & 18.88 \\
\hline & Mean & 102.73 & 46.15 & $8.19^{b}$ & 12.73 & 7.88 & 2.79 & 2.71 & 16.60 & 0.37 & 2.25 \\
\hline & S.D & 51.61 & 25.98 & 10.34 & 9.32 & 7.64 & 1.20 & 1.66 & 10.65 & 0.26 & 3.65 \\
\hline
\end{tabular}

*Different letters indicate significant differences (one-way ANOVA, LSD test, $\mathrm{p}<0.05$ ).

\section{Temporal-Spatial Variation of Heavy Metals}

The descriptive statistics of heavy metals in water samples from the Ganjiang River basin are presented in Table 2. Fe, $\mathrm{Al}$ and $\mathrm{Mn}$ were the most abundant metals in the river water, whereas $\mathrm{Cd}$, $\mathrm{Co}$ and $\mathrm{Tl}$ were less abundant. Compared with China's environmental quality standards for drinking water [33], the average concentrations of 16 heavy metals were lower than the standards. However, there were 5 heavy metals in some samples whose concentrations were higher than standard values, including Fe (16 samples), Al (12 samples), As (6 samples), Mn (3 samples), and Tl (3 samples), and the over-standard rates were $21.62 \%, 16.22 \%, 8.11 \%, 4.05 \%$ and $4.05 \%$, respectively (Fig. S2).

ANOVA showed that most heavy metal concentrations (except for $\mathrm{Cr}, \mathrm{Zn}, \mathrm{Mo}, \mathrm{Sb}$ and $\mathrm{Tl}$ ) were significantly higher in the dry season than in the wet season (Table 2). Based on HCA (Fig. S3), 37 sampling sites were categorized into four zones (Fig. S4 ), including C1 (midstream of Ganjiang River), C2 (Tao River, Zhang River, Shangyou River and the downstream of Yuan River), C3 (the source of Ganjiang River, Xiang River, Gu River, Shu River, Jin River and the upstream and midstream of Yuan River), and C4 (Ping River, Mei River, Qin River, Shuichuan River, He River and $\mathrm{Lu}$ River). Except for the metal of Al, the average concentrations of other metals in different zones have significant differences (Table 2). The average concentrations of $\mathrm{Mn}, \mathrm{Co}, \mathrm{Zn}$, As, Mo, Cd, Sb, Tl, $\mathrm{Pb}$ and $\mathrm{U}$ in the $\mathrm{C} 2$ were higher than those in others regions, while the average concentrations of $\mathrm{V}, \mathrm{Cr}$, $\mathrm{Fe}$ and $\mathrm{Cu}$ in the $\mathrm{C} 3$ were higher than those in others regions. Compared with others regions, the average concentrations of all the metals in $\mathrm{C} 4$ were lowest, indicating that water quality was relatively safe.

\section{Risk Assessment}

\section{Heavy Metal Pollution Index}

The HPI values ranged from 10.13 (Z21, wet season) to 151.76 (Z9, wet season) (Fig. 2). All sampling sites except Z9 in the wet season and Z30 in both seasons were lower than the critical pollution index limit of 100. The average HPI value in the dry season (44.97) was similar to that in the wet season (40.01), which was lower than the acceptable value (100), indicating that the surface water was generally clean as a whole and could not pose a serious threat to aquatic life and human beings in the Ganjiang River basin.

\section{Risk Assessment on Human Health}

The HQ and HI values for heavy metals via ingestion and dermal pathways for children and adults in different seasons are presented in Table S1. Both in the dry and wet seasons, the $\mathrm{HQ}_{\text {dermal }}$ values of all metals 


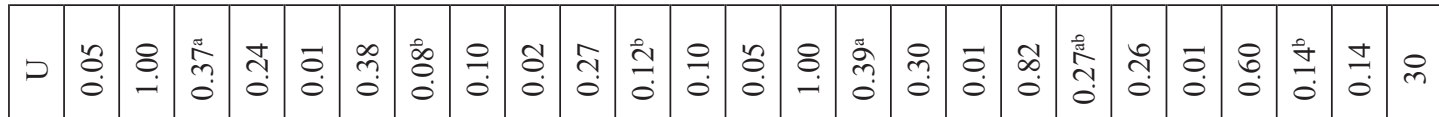

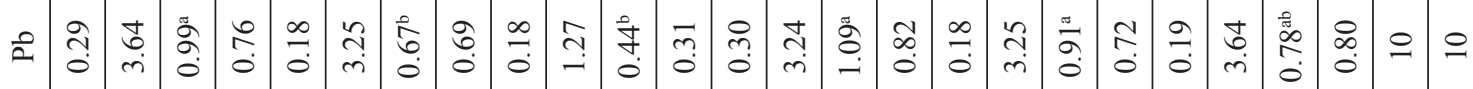

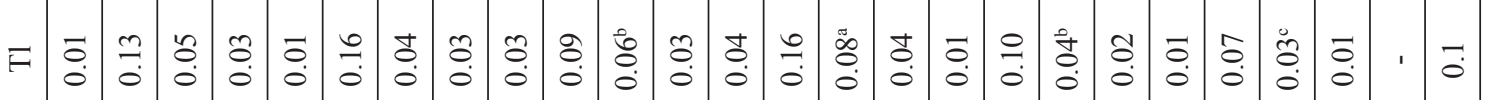

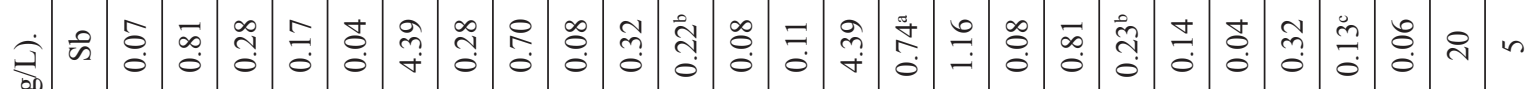
焉

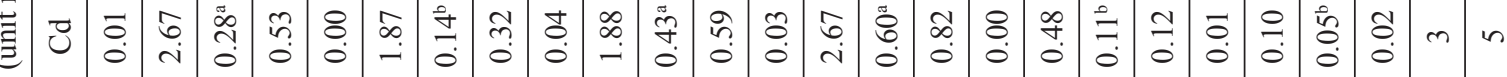

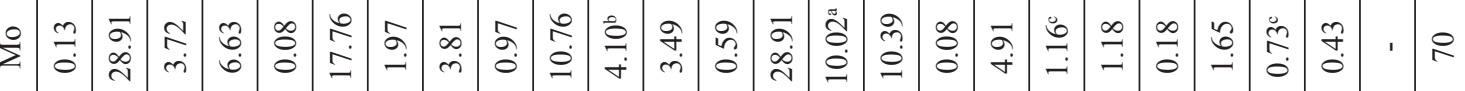

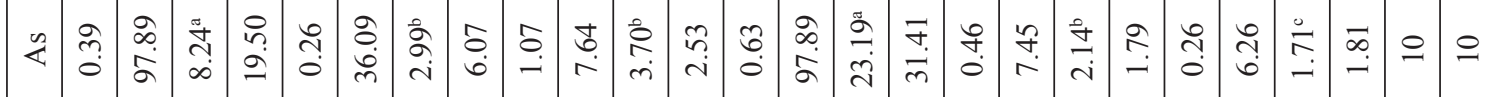

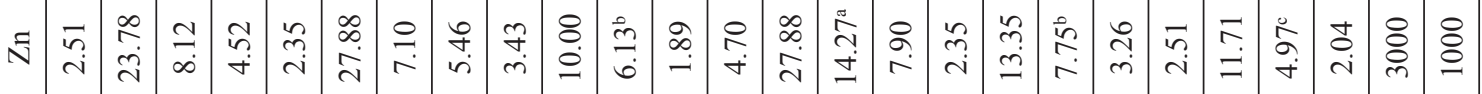

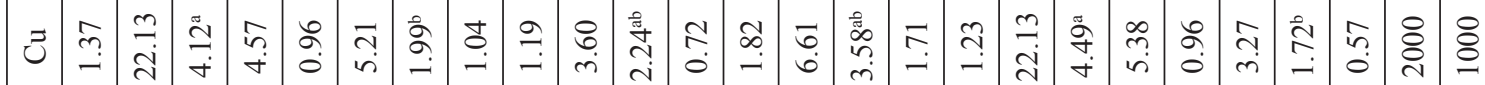

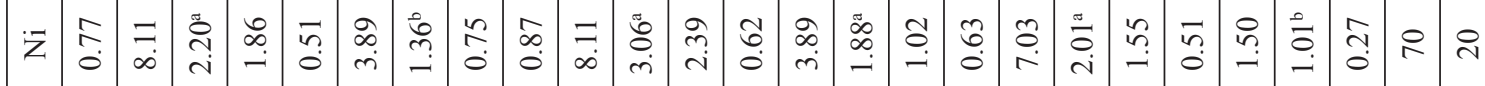

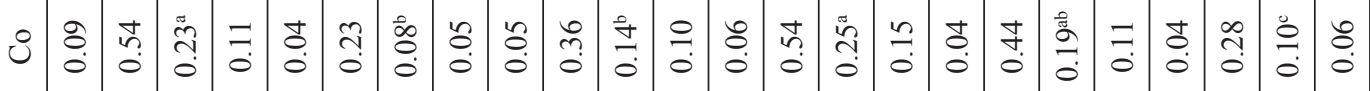

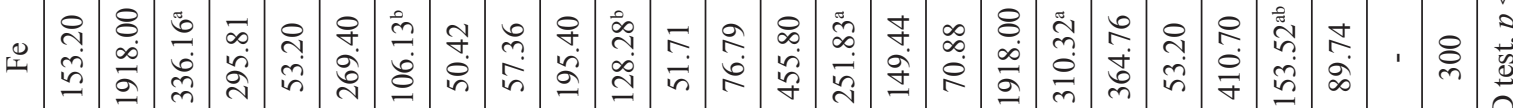

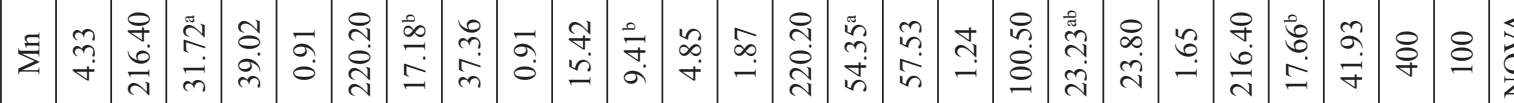

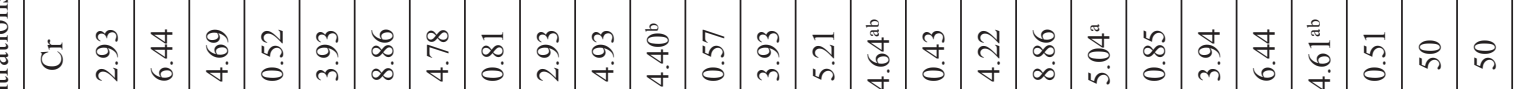

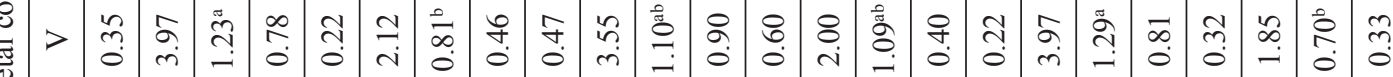

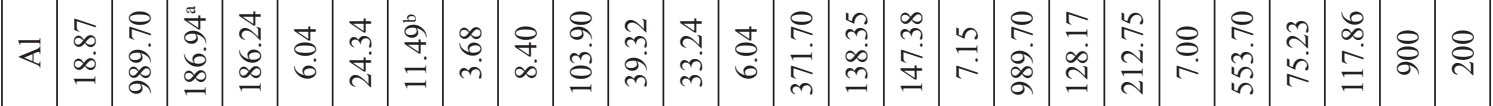

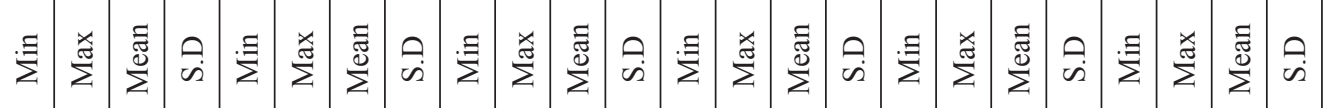




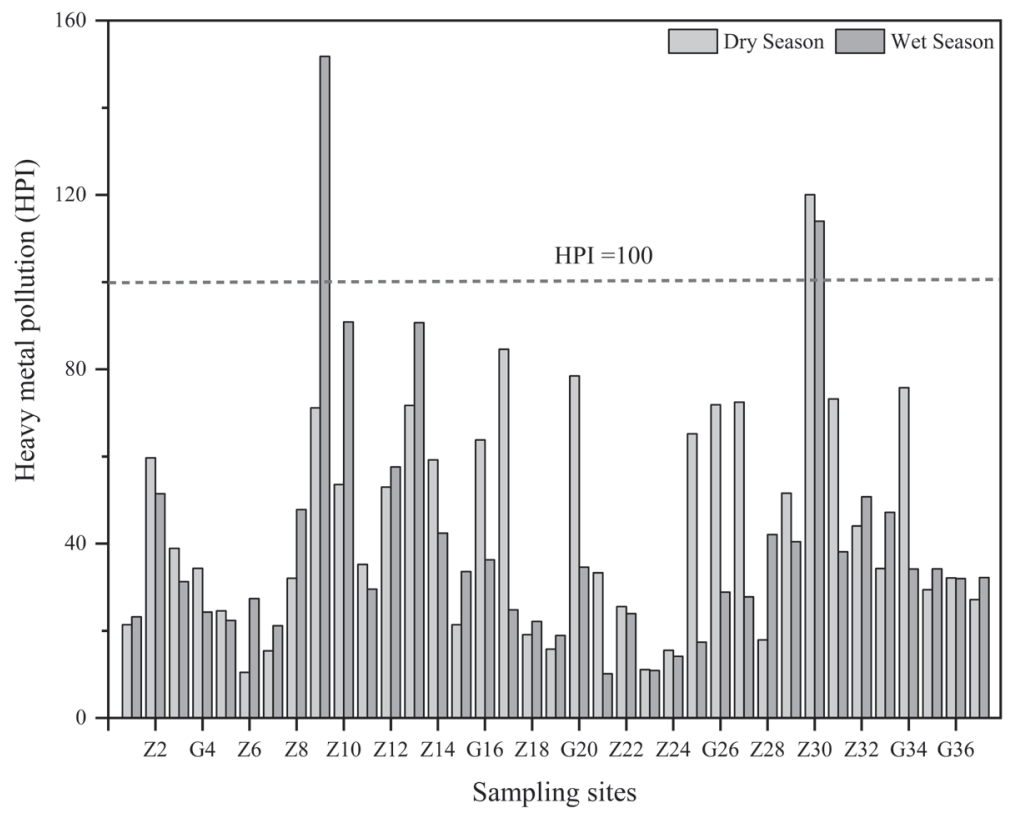

Fig. 2. Heavy metal pollution index for different seasons at 37 sites along the Ganjiang River basin with the limit value of pollution (the dotted line).

for adults and children were smaller than 1 , showing that these metals presented little hazard through dermal absorption. Similarly, in the wet season the $\mathrm{HQ}_{\text {ingestion }}$ values of all metals for adults and children were below 1. However, in the dry season the $\mathrm{HQ}_{\text {ingestion }}$ value of As for children exceeded 1, indicating that daily oral
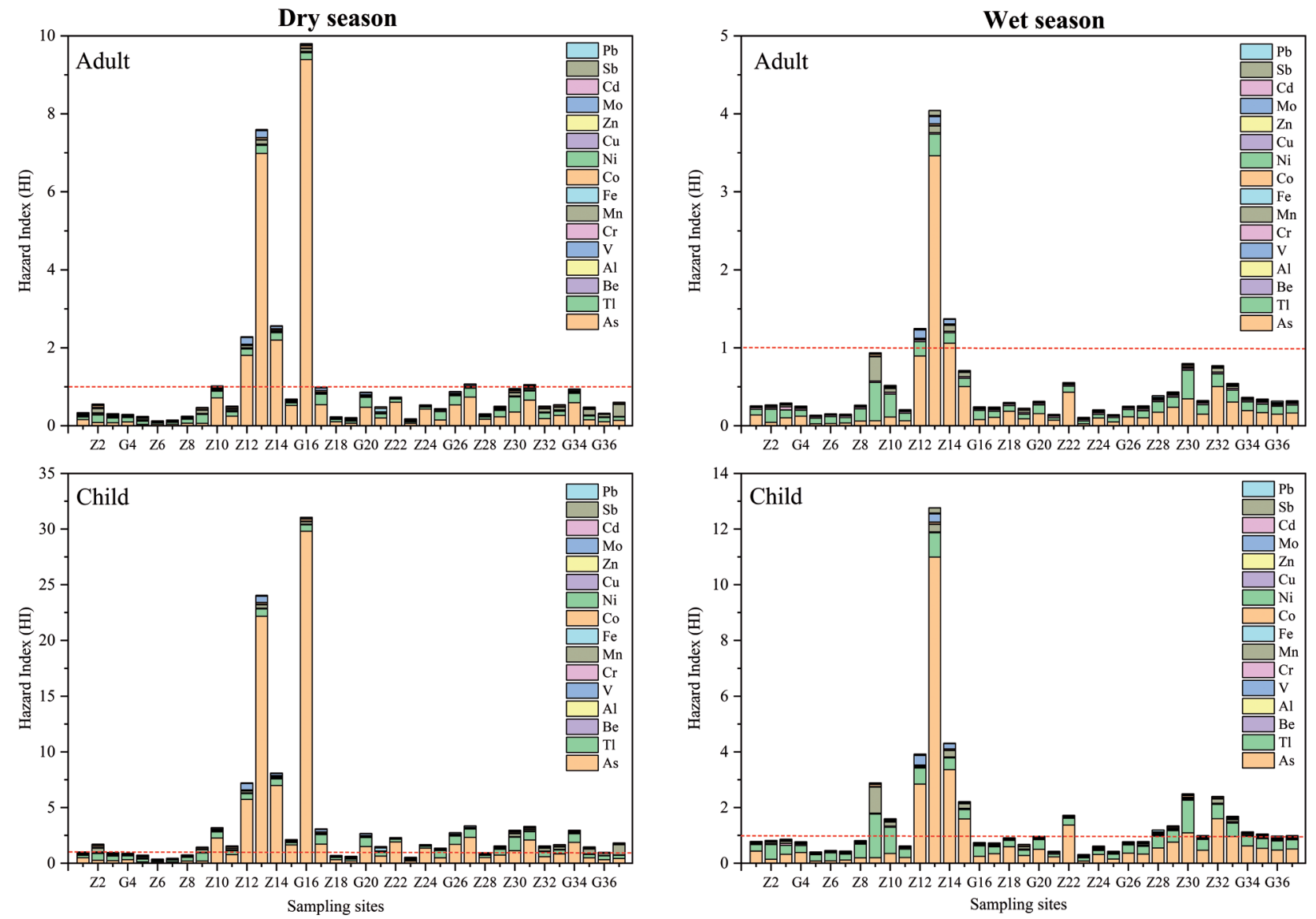

Fig. 3. Hazard index of the mixed heavy metals in the surface water from Ganjiang River basin. 

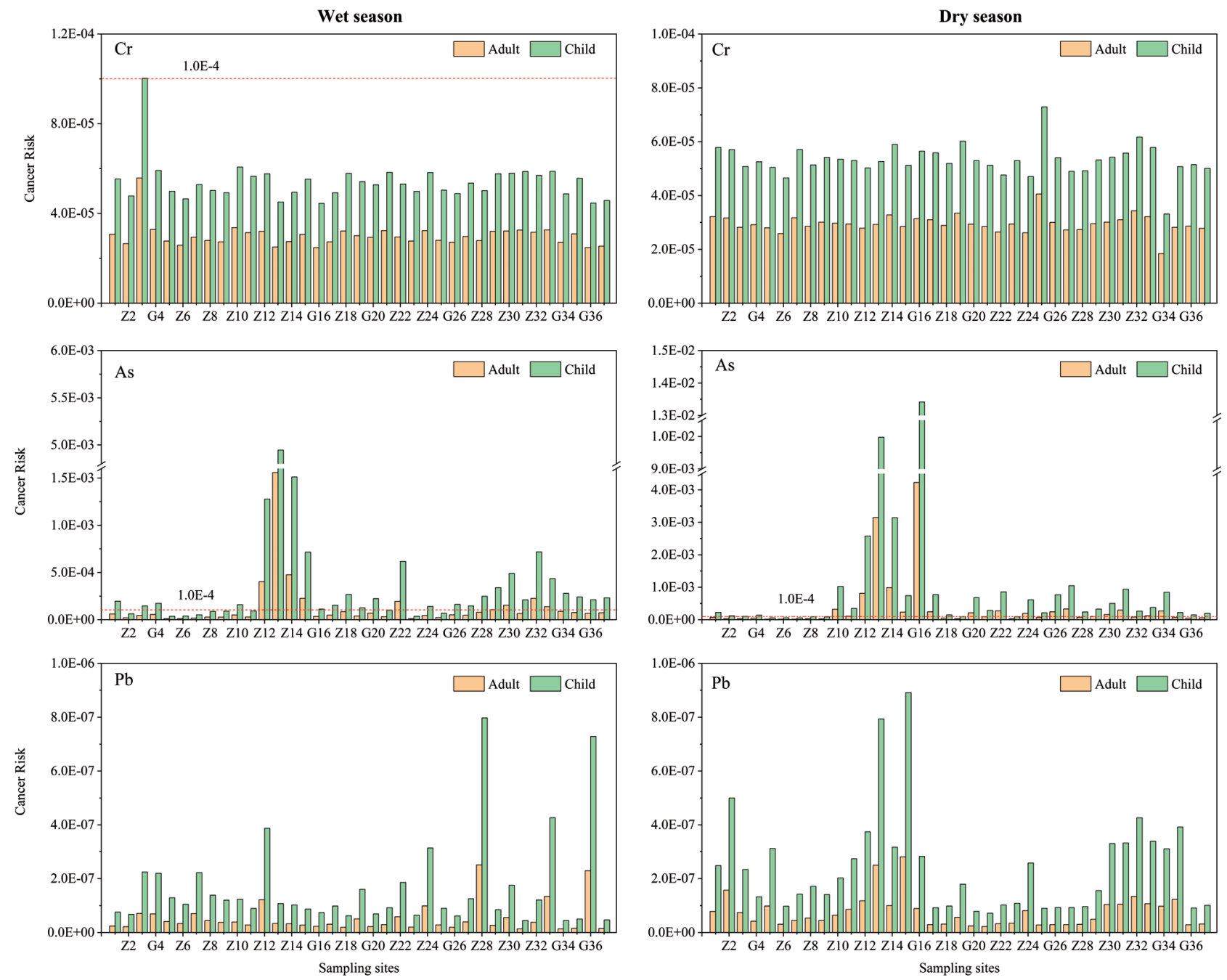

Fig. 4. Cancer risk of $\mathrm{Cr}, \mathrm{Pb}$ and $\mathrm{As}$ in surface water from Ganjiang River basin.

intake was the main pathway that pose potential noncarcinogenic risks.

The HI values of heavy metals between 37 sampling sites in both seasons for adults and children are shown in Fig. 3. In the dry season, the HI values of 7 sites for adults and 26 sites for children were more than 1 . In the wet season, 3 sites for adults and 14 sites for children were where $\mathrm{HI}$ values exceeded 1. Among them, the HI values of Z12, Z13, Z14 and G16 in the dry season and Z12, Z13 and Z14 in the wet season were obviously higher than the reference value. Compared with adults, higher HI values and the over-standard rates were observed for children, indicating that the children are more sensitive to heavy metal pollution in water. In general, the As and $\mathrm{Tl}$ was the main contributor among HI values in both seasons. For adults, the HI values of As at Z12, Z13, Z14 and Z16 in dry season and at Z13 and $Z 14$ in the wet season exceeded 1. For children, the HI values of As at Z10, Z12, Z13, Z14, Z15, G16, G17, G20, Z22, Z24, G26, G27, Z30, G31 and G34 in the dry season and at Z12, Z13, Z14, Z15, Z22, Z30 and $\mathrm{Z} 32$ in the wet season exceeded 1 , and the $\mathrm{Tl}$ at Z30 in the dry season and at Z9 and Z30 in the wet season also exceeded 1 , although it has low concentrations in the water. Therefore, we concluded that As was the largest contributor to adverse effects among the selected elements in this study.

Carcinogenic risks were calculated for $\mathrm{Cr}, \mathrm{Pb}$ and $\mathrm{As}$ because of the lack of values of CSFs for other elements. Carcinogenic risks are presented in Table S2 and Fig. 4. Similar to $\mathrm{HQ}$ values, the $\mathrm{CR}_{\text {ingestion }}$ and $\mathrm{CR}_{\text {dermal }}$ values of $\mathrm{Cr}$ and $\mathrm{Pb}$ were relatively smaller compared with the reference value, indicating that $\mathrm{Cr}$ and $\mathrm{Pb}$ in water posed a minimal hazard to local residents. However, the $\mathrm{CR}_{\text {total }}$ value of $\mathrm{Cr}$ at $\mathrm{G} 3$ in wet season for children exceeded 1.0E-4, posing a hazard to local inhabitants. Similarly, $\mathrm{CR}_{\text {ingestion }}$ values of As also exceeded the acceptable value. For adults, 18 sites (dry season) and 9 sites (wet season) of the CR values exceeded 1.0E-4, which have carcinogenic effects on the health of adults. For children, 30 sites (dry season) and 28 sites (wet season) of the CR values exceeded the reference value, indicating that it posed more adverse threats to children than adults. 


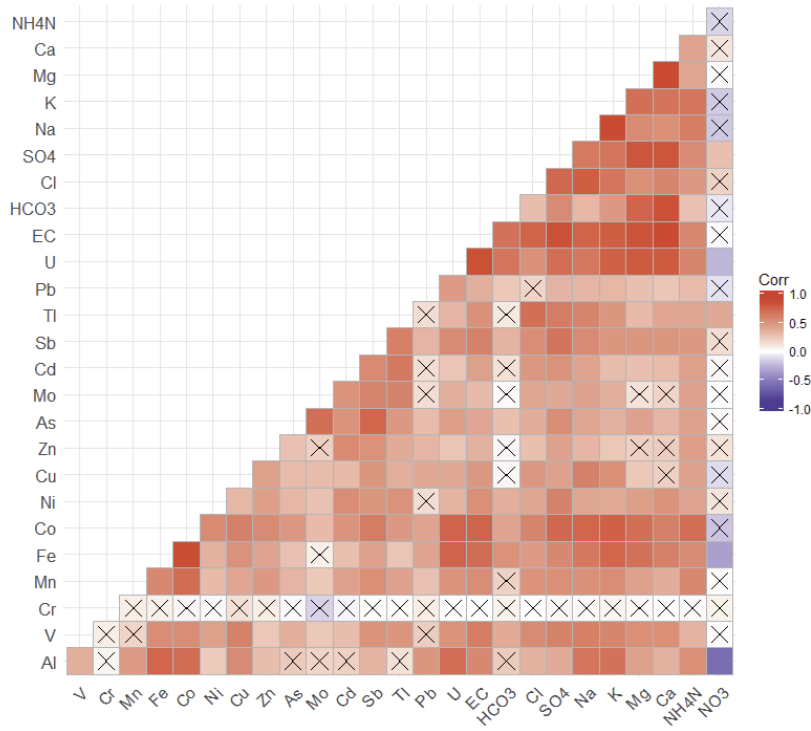

Fig. 5. Correlation heatmap of heavy metals and major hydrochemical ions in the Ganjiang River basin; " $\times$ " means insignificant correlation $(\mathrm{p}>0.05)$ and "Corr" indicates correlation.

\section{Relationship between Physico-Chemical Parameters}

\section{Correlation Analysis}

Fig. 5 shows a correlation heatmap about heavy metals and hydrochemical ions. There were significant positive correlations among $\mathrm{U}, \mathrm{EC}, \mathrm{HCO}_{3}^{-}, \mathrm{Cl}^{-}, \mathrm{SO}_{4}^{2}$, $\mathrm{Na}^{+}, \mathrm{K}^{+}, \mathrm{Mg}^{2+}, \mathrm{Ca}^{2+}, \mathrm{NH}_{4}^{+}-\mathrm{N}, \mathrm{Fe}, \mathrm{Co}, \mathrm{Mn}$ and $\mathrm{Ni}$, except between $\mathrm{Mn}$ and $\mathrm{HCO}_{-}-\mathrm{Fe}$ and $\mathrm{Mo}, \mathrm{Ni}$ and $\mathrm{Pb}$. Cr had no significant correlation with other parameters. $\mathrm{NO}_{3}$ had no significant relationship with other parameters as it had significant negative correlation with $\mathrm{Al}, \mathrm{Fe}$ and $\mathrm{U}$.

\section{Principle Component Analysis}

The results of FA/PCA are listed in Table 3. The Kaisere-Meyere-Olkin (KMO) measure was 0.827 and the significance of Bartlett's test was 0.000 , indicating that the PCA result was effective. Six principle components with eigenvalues exceeding 1 were extracted, accounting for $79.93 \%$ of the total variance. $\mathrm{PC} 1$, accounting for $21.48 \%$ of the total variance, was made up of strong positive loadings on $\mathrm{HCO}_{3}^{-}, \mathrm{Ca}^{2+}$, $\mathrm{Mg}_{2}{ }^{+}, \mathrm{U}, \mathrm{EC}, \mathrm{SO}_{4}{ }^{2-}$ and $\mathrm{Fe} . \mathrm{PC} 2$ had $16 \%$ of the total variance with strong positive correlation to $\mathrm{Cl}^{-}, \mathrm{Na}^{+}$, $\mathrm{V}, \mathrm{K}^{+}, \mathrm{Tl}$ and $\mathrm{Cu}$. PC3 explained $14.77 \%$ of the total variance and was comprised of $\mathrm{Zn}, \mathrm{Cd}, \mathrm{Mn}, \mathrm{Ni}, \mathrm{Co}$ and $\mathrm{NH}_{4}^{+}-\mathrm{N}$ with high loading. PC4 explained $11.82 \%$ of the total variance and was comprised of $\mathrm{NO}_{3}^{-}, \mathrm{Al}$ and Fe with high loadings. PC5 contributed to $10.87 \%$ of the total variance and was dominated by $\mathrm{Mo}$, As and $\mathrm{Sb}$. PC6 consisted of $\mathrm{Cr}$ and $\mathrm{Pb}$ and accounted for $4.98 \%$ of the total variance.
Table 3. Rotated component matrix of PCA on datasets of heavy metals and hydrochemical ions in the Ganjiang River basin.

\begin{tabular}{|c|c|c|c|c|c|c|}
\hline Elements & PC1 & PC2 & PC3 & PC4 & PC5 & PC6 \\
\hline $\mathrm{Al}$ & 0.23 & 0.32 & 0.23 & 0.81 & 0.06 & 0.14 \\
\hline V & 0.38 & 0.66 & 0.05 & 0.04 & 0.18 & 0.24 \\
\hline $\mathrm{Cr}$ & 0.00 & 0.09 & -0.01 & -0.10 & -0.13 & 0.76 \\
\hline $\mathrm{Mn}$ & 0.22 & 0.25 & 0.66 & 0.25 & 0.07 & 0.03 \\
\hline $\mathrm{Fe}$ & 0.52 & 0.33 & 0.38 & 0.56 & -0.07 & 0.16 \\
\hline Co & 0.46 & 0.38 & 0.57 & 0.44 & 0.17 & 0.10 \\
\hline $\mathrm{Ni}$ & 0.37 & 0.23 & 0.58 & -0.12 & 0.14 & -0.06 \\
\hline $\mathrm{Cu}$ & -0.04 & 0.61 & 0.30 & 0.33 & 0.17 & 0.39 \\
\hline $\mathrm{Zn}$ & 0.03 & 0.05 & 0.84 & 0.06 & 0.12 & 0.25 \\
\hline As & 0.26 & 0.09 & 0.19 & 0.07 & 0.86 & 0.08 \\
\hline Mo & -0.03 & 0.30 & 0.13 & 0.06 & 0.85 & -0.18 \\
\hline $\mathrm{Cd}$ & 0.08 & 0.21 & 0.68 & -0.06 & 0.42 & -0.15 \\
\hline $\mathrm{Sb}$ & 0.32 & 0.28 & 0.43 & 0.01 & 0.64 & 0.16 \\
\hline $\mathrm{Tl}$ & 0.13 & 0.61 & 0.43 & -0.29 & 0.43 & -0.05 \\
\hline $\mathrm{Pb}$ & 0.23 & -0.05 & 0.20 & 0.38 & 0.29 & 0.51 \\
\hline $\mathrm{U}$ & 0.72 & 0.27 & 0.16 & 0.46 & 0.26 & 0.05 \\
\hline $\mathrm{EC}$ & 0.73 & 0.49 & 0.31 & 0.18 & 0.15 & 0.02 \\
\hline $\mathrm{HCO}_{3}^{-}$ & 0.92 & -0.03 & -0.02 & 0.07 & 0.07 & 0.05 \\
\hline $\mathrm{Cl}^{-}$ & 0.34 & 0.76 & 0.28 & -0.05 & 0.19 & -0.08 \\
\hline $\mathrm{SO}_{4}^{2-}$ & 0.66 & 0.43 & 0.41 & -0.09 & 0.29 & 0.09 \\
\hline $\mathrm{Na}^{+}$ & 0.30 & 0.75 & 0.26 & 0.37 & 0.21 & -0.01 \\
\hline $\mathrm{K}^{+}$ & 0.50 & 0.64 & 0.20 & 0.41 & 0.12 & 0.00 \\
\hline $\mathrm{Mg}^{2+}$ & 0.88 & 0.24 & 0.19 & 0.13 & 0.09 & 0.04 \\
\hline $\mathrm{Ca}^{2+}$ & 0.92 & 0.27 & 0.18 & -0.01 & 0.08 & -0.01 \\
\hline $\mathrm{NH}_{4}^{+}-\mathrm{N}$ & 0.24 & 0.32 & 0.50 & 0.38 & 0.26 & -0.05 \\
\hline $\mathrm{NO}_{3}^{-}$ & 0.05 & 0.11 & 0.16 & -0.86 & 0.04 & 0.14 \\
\hline Eigenvalues & 5.59 & 4.16 & 3.84 & 3.07 & 2.83 & 1.30 \\
\hline $\begin{array}{c}\text { Variance } \\
(\%)\end{array}$ & 21.48 & 16.00 & 14.77 & 11.82 & 10.87 & 4.98 \\
\hline $\begin{array}{c}\text { Cumulative } \\
(\%)\end{array}$ & 21.48 & 37.48 & 52.25 & 64.07 & 74.94 & 79.93 \\
\hline
\end{tabular}

a. Bold values represent strong loadings $(>0.5)$.

As seen in Fig. S5, sites G1, Z2, G3, Z9, Z10, G11, Z12, Z13, Z14, G16, Z29, Z30, G31, Z32, Z33 and G35 in the dry season had higher correlations and contributions to $\mathrm{PC} 1$, corresponding to higher heavy metals and ion concentrations at these sites. However, sites Z5, Z6, Z7, G11, G17, Z18, G20, Z21, Z23, Z25 and G26 in the wet season had the opposite direction to PC1, corresponding to lower concentrations of heavy metals and ions at these sites. The above results also indicated that heavy 
metals and ions in the dry season had a greater impact on the Ganjiang River basin than in the wet season.

\section{Discussion}

\section{Sources Identification}

Due to the differences of geographical, environment and anthropogenic activities, the sources of heavy metals pollution in different regions have great differences $[9,11]$. However, within the same watershed, the geographical environment is basically the same, and human activities are the main factors leading to the differences [4]. Multivariate statistics analysis are an effective method to identify underlying relationships between variables, and strong correlation among elements indicates their similar chemical properties and common sources [38].

In this study, we found that $\mathrm{Fe}, \mathrm{U}, \mathrm{SO}_{4}^{2-}, \mathrm{Ca}^{2+}$, $\mathrm{Mg}^{2+}$ and $\mathrm{HCO}_{3}^{-}$showed a significant correlation, indicating similar sources (Fig. 5 and Table 3). The high concentration values were distributed in the zones of $\mathrm{C} 2$ and $\mathrm{C} 3$, especially in the Yuan River basin (Fig. S2). $\mathrm{Zn}, \mathrm{Cd}, \mathrm{Mn}, \mathrm{Ni}, \mathrm{Co}$ and $\mathrm{NH}_{4}^{+}-\mathrm{N}$ also had similar spatial variation patterns, and high concentration values were distributed in $\mathrm{C} 2$ (including the Zhang, Tao and Yuan River basins). Previous studies have revealed that $\mathrm{SO}_{4}^{2-}$ in river water was an important indicator of anthropogenic activities, especially in mining areas $[12,39,40]$. Xinyu city is a typical industrial city with abundant coal and iron storage [41]. Research results have shown that coal mining effluent [42], coal gangue dumping [43], and coal ash released by burning would cause heavy metal pollution [44]. Coal combustion also produced large amounts of $\mathrm{SO}_{4}^{2-}$, which in turn dissolved metals and non-metallic elements in minerals $[12,45]$. Moreover, steel smelting wastewater dispersed into river, resulting in increased heavy metals concentrations in river water as well. The Zhang and Tao Rivers are enrichment areas for tungsten and rare earth minerals [27-29]. Hence, we inferred that the elevated level of these metals in the region can be ascribed to large amounts of wastewater produced by tungsten mining and beneficiation operations, which is in agreement with the results of other studies in the Ganjiang River basin $[21,46]$.

$\mathrm{V}, \mathrm{Cu}, \mathrm{Tl}, \mathrm{Na}^{+}, \mathrm{K}^{+}$and $\mathrm{Cl}^{-}$showed similar variations, and high concentration values were mainly distributed in the Shu River basin, which belongs to the Jitai Basin - the second largest commodity grain base and the largest citrus production base in Jiangxi Province. Large-scale use of chlorine fertilizer and potassium fertilizer may be the main source, as reported by Samantara et al. [47]. Moreover, the application of $\mathrm{Cu}$-based fungicides, pig manure and metalcontaminated biosolids were important inputs to agricultural soils [48]. As, Mo and $\mathrm{Sb}$ also showed high concentration values in the Zhang River basin. Southern
Jiangxi Province is not only a non-ferrous metal enrichment area, but also an important agricultural field and navel orange planting area. The use of pesticides and fertilizers and the changes of land use patterns in mountainous areas leading to the release of heavy metals in rocks, which have been considered important reasons causing higher concentrations of these metals in the basin $[18,49,50]$. Arsenic is considered to be a highly toxic and carcinogenic inorganic pollutant that has attracted more and more attention around the world [51, 52]. Jia et al. [53] thought that the cause of high As in drinking water can be explained by three mechanisms, including microbial reduction and dissolution of $\mathrm{Fe}$ oxide minerals, desorption by competitive anions and subsequent reduction and release of As (V). In contrast, the toxicity of $\mathrm{Sb}$ in drinking water has not received much attention. Some studies have reported that both $\mathrm{Sb}$ and $\mathrm{As}$ are chalcophilic group $\mathrm{V}$ metalloids, which have similar chemistry and toxicity in the environment [54]. Meng et al. [55] proposed that $\mathrm{Sb}$ and As are readily dissolved from ores and rocks and released and transported into water bodies and sediments.

$\mathrm{NO}_{3}{ }^{-}$was significantly positively correlated with $\mathrm{Al}$ and $\mathrm{Fe}$ (Table 3), and the higher concentration values were distributed in the Tao and Yuan Rivers. Samantara et al. [47] demonstrated that $\mathrm{NO}_{3}^{-}$was an important ion that reflected human activities, mainly from farmland fertilization, livestock manure, urban sewage discharge and mining activities. However, Wang et al. [41], utilizing nitrogen isotopes technology, found that the high $\mathrm{NO}_{3}^{-}$concentration in the Yuan River was related to industrial wastewater, while in the Tao River $\mathrm{NO}_{3}^{-}$ was from the large amount of chemical fertilizers and agrochemicals from orange planting. In addition, the main soil type in Jiangxi Province is lateritic soil, which is known to contain large amounts of aluminum and iron. Soil erosion may also be an important pathway of $\mathrm{Fe}, \mathrm{Al}$ and $\mathrm{NO}_{3}^{-}$flow into rivers in humid subtropical monsoon climate regions. As some studies have reported, common anthropogenic sources, including mineral exploring, smelting, engineering of steel and glass could also be an important contributor of those metals in rivers [6].

$\mathrm{Cr}$ showed low spatial variation, and had no significant correlation to other parameters. Undoubtedly, the source of $\mathrm{Cr}$ could be ascribed to lithogenic control, and as reported by other studies [56, 57]. However, in contrast to the present study, other researchers have shown that high $\mathrm{Cr}$ concentrations in a river are mainly the result of intensive human activities such as production of dyes, textiles and various alloys $[49,58]$. The high concentration of $\mathrm{Pb}$ was mainly distributed in the Zhang River and Shangyou River basin, which may be related to agricultural activities. Nonetheless, other possible sources of $\mathrm{Pb}$, such as leaded gasoline, domestic sewage and atmospheric deposition, cannot be excluded [58].

Taken together, our results indicate that heavy metal pollution sources of the Ganjiang River basin were 
Table 4. Comparison of $\mathrm{Fe}, \mathrm{Al}, \mathrm{As}, \mathrm{Mn}$ and $\mathrm{Tl}$ concentrations in river water with other basins around the world (unit in $\mu \mathrm{g} / \mathrm{L}$ ).

\begin{tabular}{|c|c|c|c|c|c|c|}
\hline Rivers/Location & $\mathrm{Fe}$ & $\mathrm{Al}$ & $\mathrm{As}$ & $\mathrm{Mn}$ & $\mathrm{Tl}$ & Authors/Investigators \\
\hline Ganjiang River (China) & $221.14 \pm 240.45$ & $99.21 \pm 157.84$ & $5.61 \pm 14.58$ & $24.45 \pm 38.63$ & $0.04 \pm 0.03$ & This study \\
\hline Loess Plateau (China) & $45.4 \pm 122$ & $86.73 \pm 227$ & $5.75 \pm 5.18$ & $71.2 \pm 234$ & $0.02 \pm 0.04$ & {$[2]$} \\
\hline Dan River (China) & & $2.96 \pm 8.53$ & $7.26 \pm 10.88$ & $6.72 \pm 51.36$ & & {$[55]$} \\
\hline Han River (China) & $30.64 \pm 2.24$ & $187.99 \pm 23.99$ & $14.2 \pm 1.18$ & $30.72 \pm 9.37$ & & {$[30]$} \\
\hline $\begin{array}{c}\text { To Lich River } \\
\text { (Vietnam) }\end{array}$ & & & $39.1 \pm 18.1$ & $216.2 \pm 87.1$ & & {$[61]$} \\
\hline $\begin{array}{c}\text { Nakkavagu stream } \\
\text { (India) }\end{array}$ & $161.8 \pm 385.9$ & & $29.2 \pm 29.2$ & $72.9 \pm 77.5$ & & {$[60]$} \\
\hline $\left.\begin{array}{c}\text { Trinity River (USA) } \\
\hline \begin{array}{c}\text { Mari catchment } \\
\text { (Cameroon) }\end{array}\end{array}\right] 5.81 \pm 3.51$ & $4.81 \pm 2.67$ & & $10 \pm 0$ & $400 \pm 300$ & & {$[62]$} \\
\hline
\end{tabular}

various, and mining industries and agricultural activities were the main sources. In addition, the Yuan River basin and upstream of the Ganjiang River (in southern Jiangxi Province) were the most polluted areas.

\section{Pollution Level and Health Risk Assessment}

Low concentrations of metal, as micronutrients, are essential for life processes, but once they exceed the threshold they may pose a toxic threat to health $[2,59]$. In this study, we found several elements (including $\mathrm{Fe}, \mathrm{Al}, \mathrm{As}, \mathrm{Mn}$ and $\mathrm{Tl}$ ) whose concentrations exceeded China's water quality standard at some sampling sites. The comparison of those heavy metals in the Ganjiang River with other rivers in the world is shown in Table 4. According to the results, we found that concentrations of $\mathrm{Fe}$ and $\mathrm{Al}$ were relatively higher than the majority of rivers, whereas the concentrations of As and Mn were lower than in other rivers. The main reason for the differences was that the landscapes of different river basins were different, and the main sources of pollution were also different. For instance, Nakkavagu stream flowed through industrial and residential areas and received a large amount of sewage containing As and Mn elements, resulting in higher concentrations of metals in the river [60].

According to health risk assessment (Fig. 3), we found the number of sampling sites and $\mathrm{HI}$ values of the dry season exceeding the reference value were significantly higher than those of the wet season. The results indicated that Ganjiang River water in the dry season was more likely to pose a threat to human health. On the contrary, rich rainfall and runoff during the wet season effectively diluted the concentration of heavy metals, thereby reducing the risk of contamination [4]. Compared with adults, we found that children were more sensitive to heavy metal pollution. The result was consistent with many studies [24, 63]. Consequently, with the weak immune function and low education level of children, considerable attention should be paid to them.
Based on carcinogenic risks assessment, the result showed that As was the largest contributor to carcinogenic and non-carcinogenic effects on local residents, especially sensitive children (Fig. 4). Zhang et al. [24] also found that As was the main pollutant in the Ganjiang River. Similarly, As pollution has been found in other regions in China and other countries, such as the Chinese Loess Plateau [2], Three Gorges Reservoir [11] and 14 countries in Latin America [51]. Numerous studies have confirmed that excessive intake of arsenic can cause various carcinogenic risks and such unhealthy effects as liver cancer, bladder cancer, skin cancer, hypertension, neuropathy, and vascular diseases [2, 52]. Overall, all these findings suggest that health risks caused by As should be paid attention to.

However, since this study only analyzed the dissolved heavy metals in water, it did not analyze sediments, suspended solid metals and different fractions of heavy metals in water. Previous studies have demonstrated that the concentration of heavy metals in sediments is three to five times higher than those in the surface water [59]. Due to seasonal hydrological changes, such as hydrodynamic disturbances, redox potentials, water temperatures and $\mathrm{pH}$ values, different fractions of heavy metals could be absorbed and desorbed as well, resulting in secondary pollution $[8,56]$. In addition, there existed some uncertainties of the risk assessment parameters, including ED (exposure duration), BW (body weight), SA (exposed skin area) and so on, depending on different regions, different pollution sources and receptors [37, 39]. Hence, more work should be carried out in the basin in order to protect aquatic ecosystems.

\section{Conclusions}

Heavy metal pollution has drawn worldwide attention in recent decades. Similarly, heavy metal pollution in China is one of the hottest topics. The aim of this study was to look at the characteristics and sources of heavy metals and their potential risk assessment 
in the Ganjiang River basin. Results showed that the concentrations of hydrochemical ions and heavy metals exhibited significant seasonal variations and spatial heterogeneity. Several metals selected in this study (including $\mathrm{Fe}, \mathrm{Al}, \mathrm{As}, \mathrm{Mn}$ and $\mathrm{Tl}$ ) had concentrations that exceeded the water quality standard at some sampling sites. Mining industries and agricultural activities were the main sources of heavy metal pollution in the Ganjiang River basin, while the Yuan River basin and upstream of Ganjiang River (the southern of Jiangxi Province) were the most polluted areas. Based on health risk assessment, ingestion was the main pathway that posed an adverse challenge and risk to human health, and As was the largest contributor, causing carcinogenic and non-carcinogenic risks to humans - in particular for children, who should be paid more attention from local governments to control and manage the pollution.

\section{Acknowledgements}

This work was supported by the National Natural Science Foundation of China (41661017, 41201033), the Natural Science Foundation of Jiangxi Province, and the Collaborative Innovation Center for Major Ecological Security Issues of Jiangxi Province and Monitoring Implementation [JXS-EW-00]. We acknowledge the editors and reviewers for polishing the language of our paper and for their in-depth discussion.

\section{Conflict of Interest}

The authors declare no conflict of interest.

\section{References}

1. AZIZULLAH A., KHATTAK M., RICHTER P., HÄDER D. Water pollution in Pakistan and its impact on public health - A review. Environment International. 37 (2), 479, 2011.

2. XIAO J., WANG L., DENG L., JIN Z. Characteristics, sources, water quality and health risk assessment of trace elements in river water and well water in the Chinese Loess Plateau. Science of the Total Environment. 650, 2004, 2019.

3. LU H., YU S. Spatio-temporal variational characteristics analysis of heavy metals pollution in water of the typical northern rivers, China. Journal of Hydrology. 559, 787, 2018.

4. WANG X., ZHANG L., ZHAO Z., CAI Y. Heavy metal pollution in reservoirs in the hilly area of southern China: Distribution, source apportionment and health risk assessment. Science of the Total Environment. 634, 158, 2018.

5. DUODU G., GOONETILlEKE A., AYOKO G. Comparison of pollution indices for the assessment of heavy metal in Brisbane River sediment. Environmental Pollution. 219, 1077, 2016.
6. SINGH U., KUMAR B. Pathways of heavy metals contamination and associated human health risk in Ajay River basin, India. Chemosphere. 174, 183, 2017.

7. LI Z., MA Z., van der KUIJP T., YUAN Z., HUANG L. A review of soil heavy metal pollution from mines in China: Pollution and health risk assessment. Science of the Total Environment. 468-469, 843, 2014.

8. BING H., ZHOU J., WU Y., WANG X., SUN H., LI R. Current state, sources, and potential risk of heavy metals in sediments of Three Gorges Reservoir, China. Environmental Pollution. 214, 485, 2016.

9. WANG J., LIU G., LIU H., LAM P. Multivariate statistical evaluation of dissolved trace elements and a water quality assessment in the middle reaches of Huaihe River, Anhui, China. Science of the Total Environment. 583, 421, 2017.

10. LI S., ZHANG Q. Risk assessment and seasonal variations of dissolved trace elements and heavy metals in the Upper Han River, China. Journal of Hazardous Materials. 181 (1-3), 1051, 2010.

11. GAO Q., LI Y., CHENG Q., YU M., HU B., WANG Z., YU $Z$. Analysis and assessment of the nutrients, biochemical indexes and heavy metals in the Three Gorges Reservoir, China, from 2008 to 2013. Water Research. 92, 262, 2016.

12. RAKOTONDRABE F., NDAM NGOUPAYOU J., MFONKA Z., RASOLOMANANA E., NYANGONO ABOLO A., AKO AKO A. Water quality assessment in the Bétaré-Oya gold mining area (East-Cameroon): Multivariate Statistical Analysis approach. Science of the Total Environment. 610-611, 831-844, 2018.

13. KEEFE S., BARBER L., HUBBARD L., BRADLEY P., ROTH D., KOLPIN D. Behavior of major and trace elements in a transient surface water/groundwater system following removal of a long-term wastewater treatment facility source. Science of the Total Environment. 668, 867, 2019.

14. VAROL M., ŞEN B. Assessment of nutrient and heavy metal contamination in surface water and sediments of the upper Tigris River, Turkey. Catena. 92, 1, 2012.

15. ZHANG Z., LU Y., LI H., TU Y., LIU B., YANG Z. Assessment of heavy metal contamination, distribution and source identification in the sediments from the Zijiang River, China. Science of the Total Environment. 645, 235, 2018.

16. ABRAHAM M., SUSAN T. Water contamination with heavy metals and trace elements from Kilembe copper mine and tailing sites in Western Uganda; implications for domestic water quality. Chemosphere. 169, 281, 2017.

17. ANTONIADIS V., SHAHEEN S., LEVIZOU E., SHAHID M., NIAZI N., VITHANAGE M., OK Y., BOLAN N., RINKLEBE J. A critical prospective analysis of the potential toxicity of trace element regulation limits in soils worldwide: Are they protective concerning health risk assessment? - A review. Environment International. 127, 819, 2019.

18. AHMED N., BODRUD-DOZA M., TOWFIQUL ISLAM A., HOSSAIN S., MONIRUZZAMAN M., DEB N., BHUIYAN M. Appraising spatial variations of As, Fe, Mn and $\mathrm{NO}_{3}$ contaminations associated health risks of drinking water from Surma basin, Bangladesh. Chemosphere. 218, 726, 2019.

19. SLAM A.R.M.T., AHMED N., BODRUD-DOZA M., CHU $R$. Characterizing groundwater quality ranks for drinking purposes in Sylhet district, Bangladesh, using entropy method, spatial autocorrelation index, and geostatistics. Environmental Science and Pollution Research. 24 (34), 26350, 2017. 
20. XIAO Y., ZHANG X., WAN H., WANG Y., LIU C., XIA J. Spatial and temporal characteristics of rainfall across Ganjiang River Basin in China. Meteorology and Atmospheric Physics. 128 (2), 167, 2016.

21. JI Y., ZHANGI J., HUANG X., BAI C., CHEN X. Investigation and assessment of heavy metals in surface sediments of Ganjiang River, China. Journal of Environmental Biology. 35 (6), 1173, 2014.

22. LIU W., LI Z., ZOU D.S., REN C., PEI Q. The characteristics and evaluation of water pollution in Ganjiang Tail River. Iop Conference Series: Earth and Environmental Science. 82, $12022,2017$.

23. HU C., ZHOU P., HUNAG P., DU J., ZHOU W. Behavior characteristics of dissolved heavy metals and health risks assessment from Poyang Lake Basin, China. Journal of Agro-Environment Science. 31 (5), 1009, 2012 [In Chinese].

24. ZHANG H., JIANG Y., WANG M., WANG P., SHI G., DING M. Spatial characterization, risk assessment, and statistical source identification of the dissolved trace elements in the Ganjiang River - feeding tributary of the Poyang Lake, China. Environmental Science and Pollution Research. 24 (3), $2890,2017$.

25. JIANG Y., XIE Z., ZHANG H., ZHANG H., WU Y., XIONG T. Effect of land use structure and social economy on concentrations of dissolved heavy metal in Ganjiang River Basin. Acta Scientiae Circumstantiae. 37 (7), 2531, 2017 [In Chinese].

26. ZHANG H., WAN Z., DING M., WANG P., XU X., JIANG Y. Inherent bacterial community response to multiple heavy metals in sediment from river-lake systems in the Poyang Lake, China. Ecotoxicology and Environmental Safety. 165, 314, 2018.

27. FENG C., ZENG Z., ZHANG D., QU W., DU A., LI D., SHE H. SHRIMP zircon U-Pb and molybdenite $\mathrm{Re}-\mathrm{Os}$ isotopic dating of the tungsten deposits in the Tianmenshan-Hongtaoling W-Sn orefield, southern Jiangxi Province, China, and geological implications. Ore Geology Reviews. 43 (1), 8, 2011.

28. FENG C., ZHANG Z., WANG S. Chronology of the Tungsten Deposits in Southern Jiangxi Province, and Episodes and Zonation of the Regional W-Sn Mineralization - Evidence from High-precision Zircon $\mathrm{U}-\mathrm{Pb}$, Molybdenite Re-Os and Muscovite Ar-Ar Ages. Acta Geologica Sinica - English Edition. 86 (3), 555, 2012.

29. BROOKES K. What's new in Chinese tungsten. Metal Powder Report. 66 (6), 22, 2011.

30. LI S., ZHANG Q. Spatial characterization of dissolved trace elements and heavy metals in the upper Han River (China) using multivariate statistical techniques. Journal of Hazardous Materials. 176 (1-3), 579, 2010.

31. BU H., WANG W., SONG X., ZHANG Q. Characteristics and source identification of dissolved trace elements in the Jinshui River of the South Qinling Mts., China. Environmental Science and Pollution Research. 22 (18), 14248, 2015.

32. REZA R., SINGH G. Heavy metal contamination and its indexing approach for river water. International Journal of Environmental Science \& Technology. 7 (4), 785, 2010.

33. MINISTRY OF HEALTH. Standards for Drinking Water Quality (GB5749-2006). Ministry of Health of the People's Republic of China, Beijing. 2006.

34. WHO. Guidelines for Drinking-water Quality Recommendations. fourth edition. World Health Organization, Geneva. 2011.
35. MOHAN S., NITHILA P., REDDY S. Estimation of heavy metals in drinking water and development of heavy metal pollution index. Journal of Environmental Science and Health. Part A: Environmental Science and Engineering and Toxicology. 31 (2), 283, 2008.

36. US EPA. Risk Assessment Guidance for Superfund (RAGS). Volume I: Human Health Evaluation Manual (Part E, Supplemental Guidance for Dermal Risk Assessment) Final. U.S. Environmental Protection Agency, Washington DC. 2004.

37. WU B., ZHAO D., JIA H., ZHANG Y., ZHANG X., CHENG S. Preliminary Risk Assessment of Trace Metal Pollution in Surface Water from Yangtze River in Nanjing Section, China. Bulletin of Environmental Contamination and Toxicology. 82 (4), 405, 2009.

38. ZHANG Z., ABUDUWAILI J., JIANG F. Heavy metal contamination, sources, and pollution assessment of surface water in the Tianshan Mountains of China. Environmental Monitoring and Assessment. 187 (2), 2015.

39. LI S., ZHANG Q. Geochemistry of the upper Han River basin, China2: Seasonal variations in major ion compositions and contribution of precipitation chemistry to the dissolved load. Journal of Hazardous Materials. 170 (2-3), 605, 2009.

40. BHUIYAN M., ISLAM M., DAMPARE S., PARVEZ L., SUZUKI S. Evaluation of hazardous metal pollution in irrigation and drinking water systems in the vicinity of a coal mine area of northwestern Bangladesh. Journal of Hazardous Materials. 179 (1-3), 1065, 2010.

41. WANG P., LIU J., QI S., WANG S., CHEN X. Tracing sources of nitrate using water chemistry, land use and nitrogen isotopes in the Ganjiang River, China. Isotopes in Environmental and Health Studies. 53 (5), 539, 2017.

42. MISHRA V., UPADHYAYA A., PANDEY S., TRIPATHI B. Heavy metal pollution induced due to coal mining effluent on surrounding aquatic ecosystem and its management through naturally occurring aquatic macrophytes. Bioresource Technology. 99 (5), 930, 2008.

43. JIANG X., LU W., YANG Q., YANG Z. Potential ecological risk assessment and prediction of soil heavy metal pollution around coal gangue dump. Natural Hazards and Earth System Sciences Discussions. 2 (3), 1977, 2014.

44. LI J., SUN C. Evaluation of the migration of thallium, cadmium, vanadium, and chromium from a thermal power plant. Environmental Earth Sciences. 75 (5), 2016.

45. CAO Y., TANG C., SONG X., LIU C. Major ion chemistry, chemical weathering and $\mathrm{CO}_{2}$ consumption in the Songhua River basin, Northeast China. Environmental Earth Sciences. 73 (11), 7505, 2015.

46. ZHANG H., JIANG Y., DING M., XIE Z. Level, source identification, and risk analysis of heavy metal in surface sediments from river-lake ecosystems in the Poyang Lake, China. Environmental Science and Pollution Research. 24 (27), 21902, 2017.

47. SAMANTARA M., PADHI R., SOWMYA M., KUMARAN P., SATPATHY K. Heavy metal contamination, major ion chemistry and appraisal of the groundwater status in coastal aquifer, Kalpakkam, Tamil Nadu, India. Groundwater for Sustainable Development. 5, 49, 2017.

48. LIU B., LI Y., GAO S., CHEN X. Copper exposure to soil under single and repeated application: Selection for the microbial community tolerance and effects on the dissipation of antibiotics. Journal of Hazardous Materials. 325, 129, 2017. 
49. GIRI S., SINGH A.K. Risk assessment, statistical source identification and seasonal fluctuation of dissolved metals in the Subarnarekha River, India. Journal of Hazardous Materials. 265, 305, 2014.

50. KÄNDLER M., BLECHINGER K., SEIDLER C., PAVLŮ V., ŠANDA M., DOSTÁL T., KRÁSA J., VITVAR T., ŠTICH M. Impact of land use on water quality in the upper Nisa catchment in the Czech Republic and in Germany. Science of the Total Environment. 586, 1316, 2017.

51. BUNDSCHUH J., LITTER M., PARVEZ F., ROMÁNROSS G., NICOLLI H.B., JEAN J., LIU C., LÓPEZ D., ARMIENTA M., GUILHERME L., CUEVAS A., CORNEJO L., CUMBAL L., TOUJAGUEZ R. One century of arsenic exposure in Latin America: A review of history and occurrence from 14 countries. Science of the Total Environment. 429, 2, 2012.

52. MANDAL B., SUZUKI K. Arsenic round the world: a review. Talanta. 58 (1), 201, 2002.

53. JIA Y., GUO H., JIANG Y., WU Y., ZHOU Y. Hydrogeochemical zonation and its implication for arsenic mobilization in deep groundwaters near alluvial fans in the Hetao Basin, Inner Mongolia. Journal of Hydrology. 518, 410, 2014

54. WILSON N., CRAW D., HUNTER K. Antimony distribution and environmental mobility at an historic antimony smelter site, New Zealand. Environmental Pollution. 129 (2), 257, 2004.

55. MENG Q., ZHANG J., ZHANG Z., WU T. Geochemistry of dissolved trace elements and heavy metals in the Dan River Drainage (China): distribution, sources, and water quality assessment. Environmental Science and Pollution Research. 23 (8), 8091, 2016.

56. MA X., ZUO H., LIU J., LIU Y. Distribution, risk assessment, and statistical source identification of heavy metals in aqueous system from three adjacent regions of the Yellow River. Environmental Science and Pollution Research. 23 (9), 8963, 2016.

57. CHEN H., TENG Y., LI J., WU J., WANG J. Source apportionment of trace metals in river sediments: A comparison of three methods. Environmental Pollution. 211, 28, 2016.

58. ALI M., ALI M., ISLAM M., RAHMAN M. Preliminary assessment of heavy metals in water and sediment of Karnaphuli River, Bangladesh. Environmental Nanotechnology, Monitoring \& Management. 5, 27, 2016.

59. DAI L., WANG L., LI L., LIANG T., ZHANG Y., MA C., XING B. Multivariate geostatistical analysis and source identification of heavy metals in the sediment of Poyang Lake in China. Science of the Total Environment. 621, 1433, 2018.

60. KRISHNA A., SATYANARAYANAN M., GOVIL P. Assessment of heavy metal pollution in water using multivariate statistical techniques in an industrial area: A case study from Patancheru, Medak District, Andhra Pradesh, India. Journal of Hazardous Materials. 167 (1-3), 366, 2009.

61. THUONG N., YONEDA M., IKEGAMI M., TAKAKURA $M$. Source discrimination of heavy metals in sediment and water of To Lich River in Hanoi City using multivariate statistical approaches. Environmental Monitoring and Assessment. 185 (10), 8065, 2013.

62. WARNKEN K., SANTSCHI P. Delivery of Trace Metals (Al, Fe, Mn, V, Co, Ni, Cu, Cd, Ag, Pb) from the Trinity River Watershed Towards the Ocean. Estuaries and Coasts. 32 (1), 158, 2009.

63. JIANG Y., XIE H., ZHANG H., XIE Z., CAO Y. Dissolved Heavy Metals Distribution and Risk Assessment in the Le'an River Subjected to Violent Mining Activities. Polish Journal of Environmental Studies. 27 (4), 1559, 2018. 


\section{Supplementary Material}
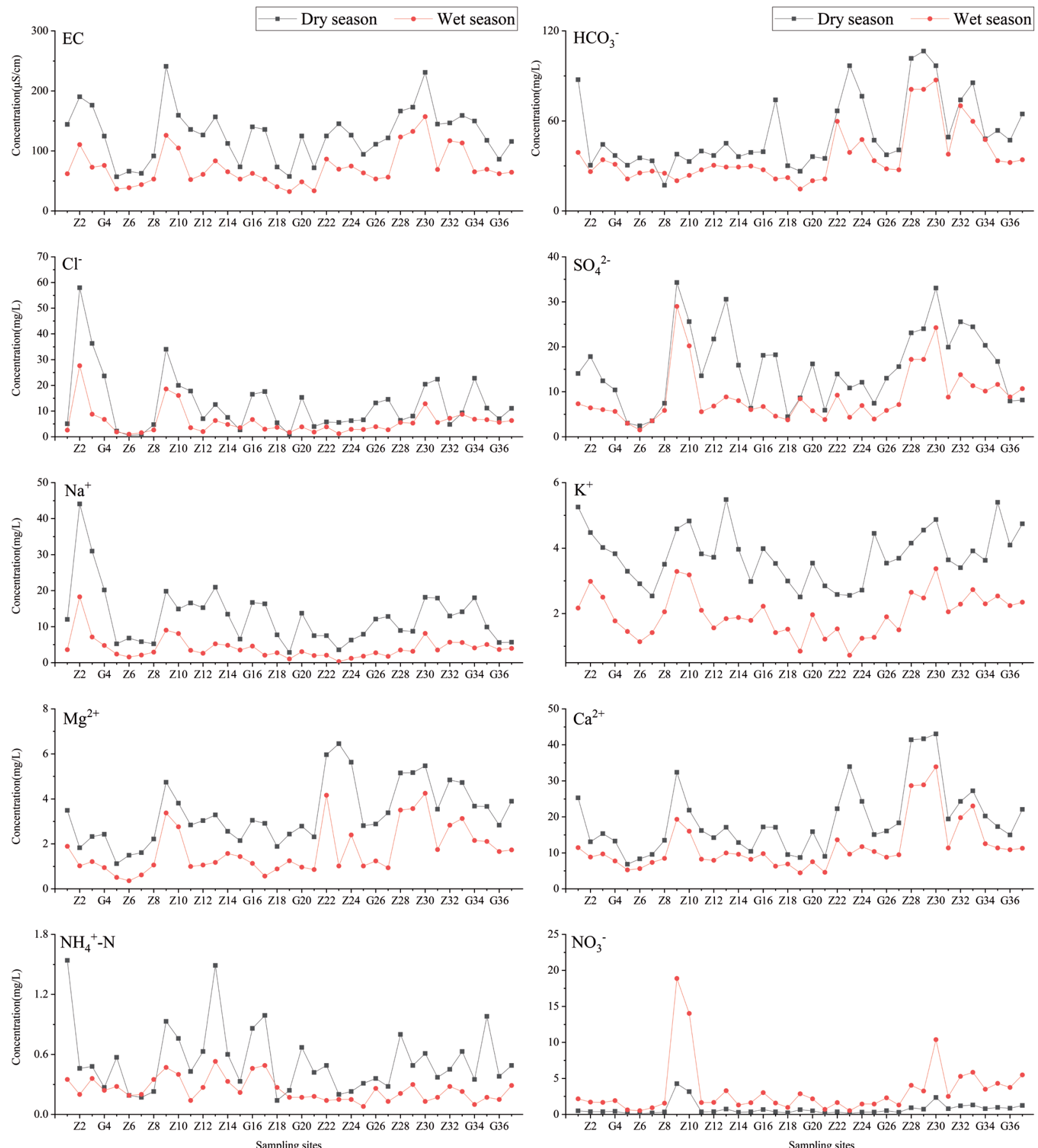

Fig. S1. Spatial-temporal variabilities of physico-chemistry paramaters in 37 sampling sites from Ganjiang River basin. 

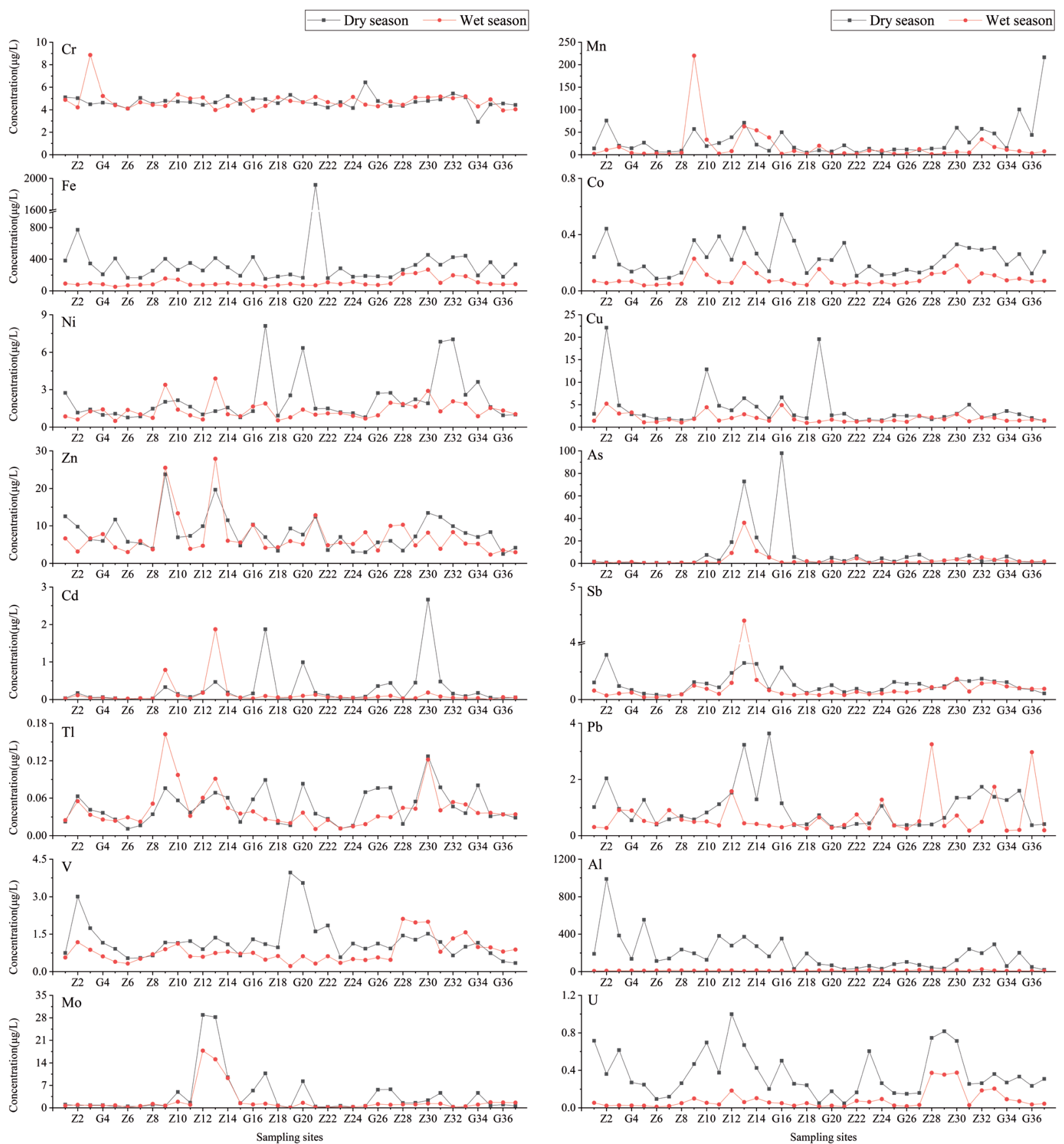

Fig. S2. Spatial-temporal variabilities of 16 heavy metals in 37 sampling sites from Ganjiang River basin. 


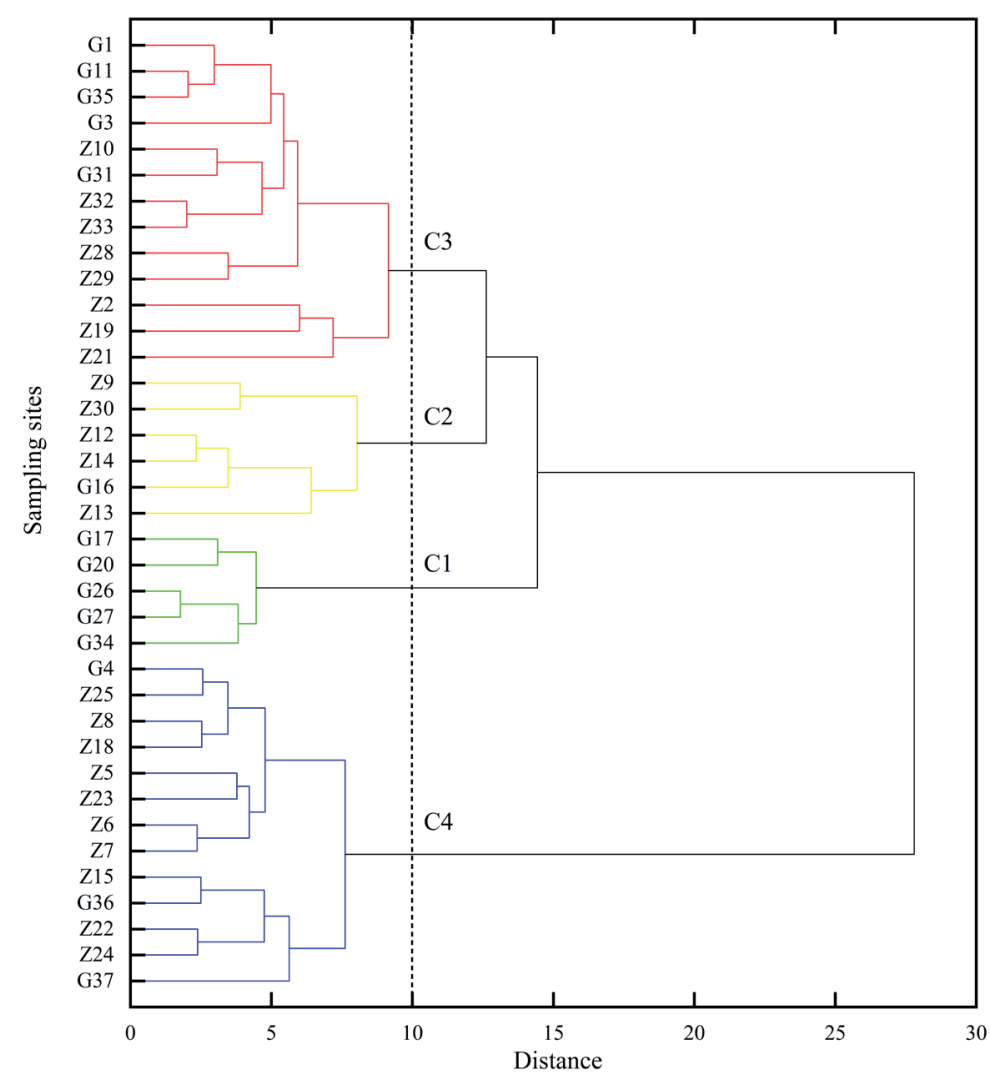

Fig. S3. Dendrogram based on hierarchical clustering analysis for the 37 sampling sites in the Ganjiang River basin..

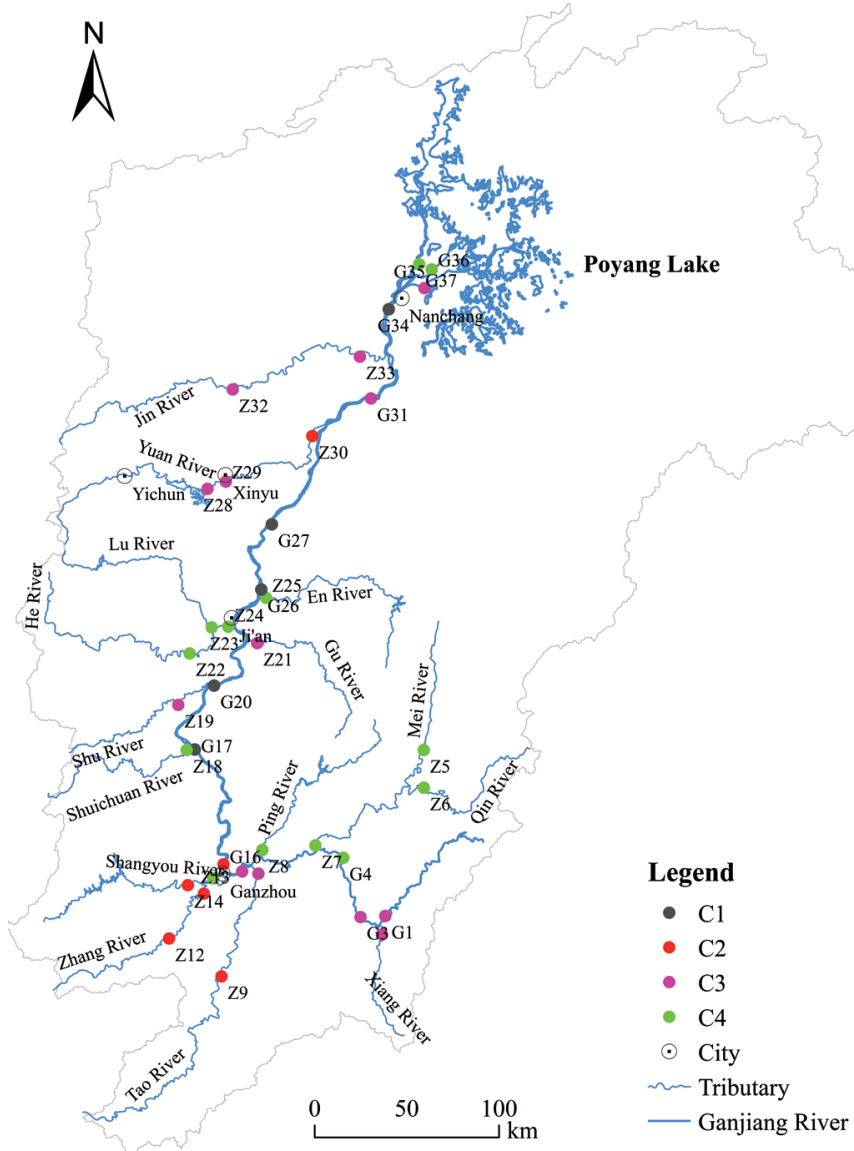

Fig. S4. Sampling sites based on hierarchical clustering analysis in the Ganjiang River basin. 


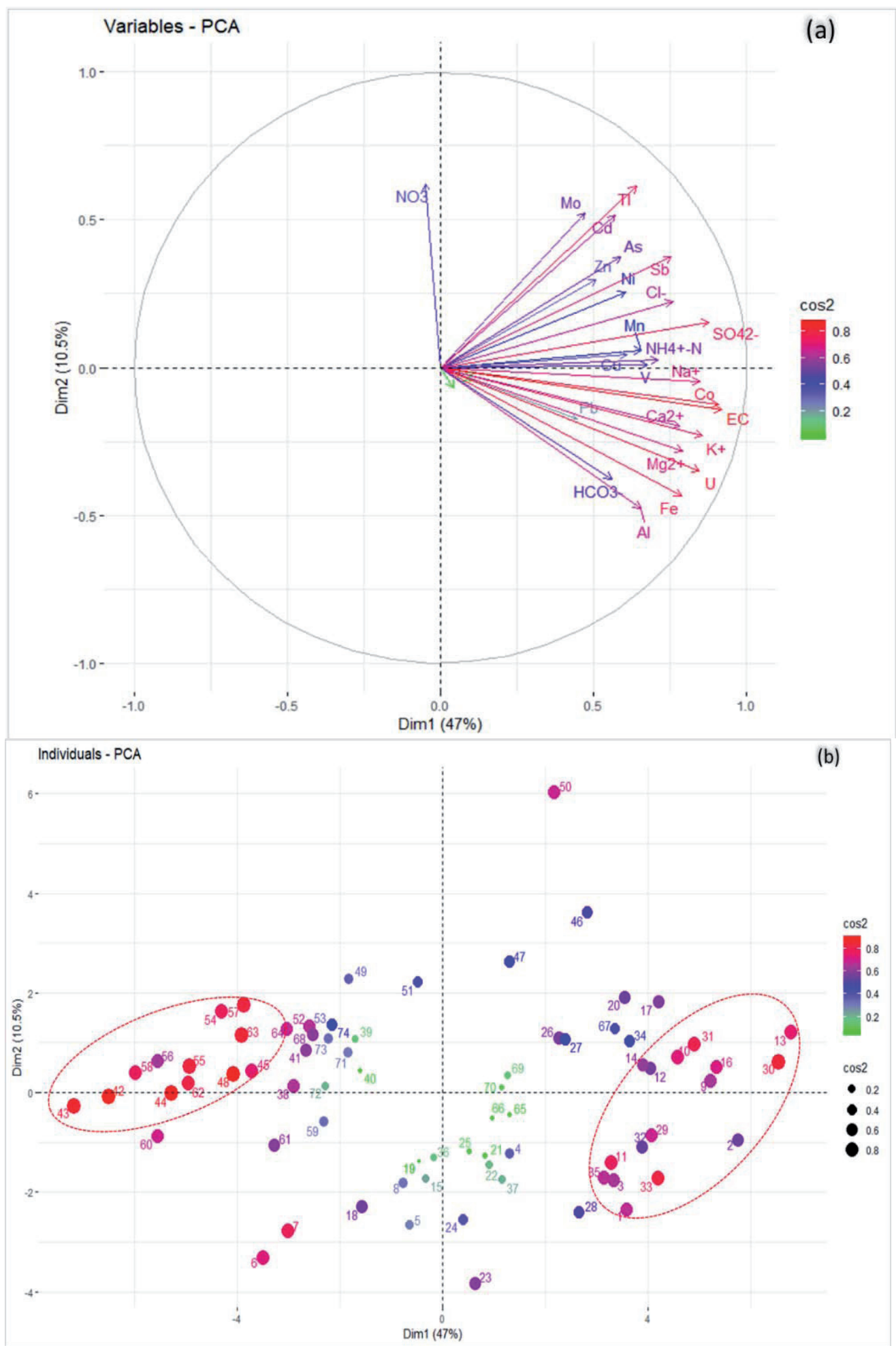

Fig. S5. Principal component analysis (PCA) of heavy metals and hydrochemical ions in Ganjiang River basin (individuals: 1 37 stand for the sampling site G1 G37 in the dry season and 38 74 stand for sampling sites G1 G37 in the wet season; cos2 values are used to estimate the quality of the representation). 
Table S1. Dermal permeability coefficient, reference dose and hazard quotient for heavy metals in Ganjiang River basin.

\begin{tabular}{|c|c|c|c|c|c|c|c|c|c|c|}
\hline \multirow{2}{*}{ Element } & \multirow{2}{*}{ Deason } & \multirow{2}{*}{$\frac{\mathrm{Kp}}{(\mathrm{cm} / \mathrm{h})}$} & \multirow{2}{*}{$\begin{array}{c}\text { RfDingestion } \\
\text { (ug/kg/day) }\end{array}$} & \multirow{2}{*}{\begin{tabular}{l|} 
RfDdermal \\
(ug/kg/day) \\
\end{tabular}} & \multicolumn{2}{|c|}{ HQingestion } & \multicolumn{2}{|c|}{ HQdermal } & \multicolumn{2}{|c|}{ HI } \\
\hline & & & & & Adult & Child & Adult & Child & Adult & Child \\
\hline $\mathrm{Be}$ & dry & $1.00 \mathrm{E}-03$ & 2 & 1 & $3.30 \mathrm{E}-06$ & $1.05 \mathrm{E}-05$ & 4.63E-06 & 7.92E-06 & 7.92E-06 & $1.84 \mathrm{E}-05$ \\
\hline $\mathrm{Be}$ & wet & $1.00 \mathrm{E}-03$ & 2 & 1 & $8.12 \mathrm{E}-07$ & $2.59 \mathrm{E}-06$ & $1.14 \mathrm{E}-06$ & $1.95 \mathrm{E}-06$ & $1.95 \mathrm{E}-06$ & 4.54E-06 \\
\hline $\mathrm{Al}$ & dry & $1.00 \mathrm{E}-03$ & 1000 & 200 & $5.63 \mathrm{E}-03$ & $1.79 \mathrm{E}-02$ & $1.38 \mathrm{E}-04$ & $2.37 \mathrm{E}-04$ & $5.77 \mathrm{E}-03$ & $1.82 \mathrm{E}-02$ \\
\hline $\mathrm{Al}$ & wet & $1.00 \mathrm{E}-03$ & 1000 & 200 & $3.46 \mathrm{E}-04$ & $1.10 \mathrm{E}-03$ & $8.50 \mathrm{E}-06$ & $1.45 \mathrm{E}-05$ & $3.55 \mathrm{E}-04$ & $1.12 \mathrm{E}-03$ \\
\hline V & dry & $1.00 \mathrm{E}-03$ & 5 & 0.13 & $1.93 \mathrm{E}-04$ & $6.14 \mathrm{E}-04$ & $1.40 \mathrm{E}-03$ & $2.40 \mathrm{E}-03$ & $1.59 \mathrm{E}-03$ & $3.01 \mathrm{E}-03$ \\
\hline V & wet & $1.00 \mathrm{E}-03$ & 5 & 0.13 & $1.27 \mathrm{E}-04$ & 4.06E-04 & $9.26 \mathrm{E}-04$ & $1.58 \mathrm{E}-03$ & $1.05 \mathrm{E}-03$ & $1.99 \mathrm{E}-03$ \\
\hline $\mathrm{Cr}$ & dry & $2.00 \mathrm{E}-03$ & 3 & 0.075 & $1.18 \mathrm{E}-03$ & $3.75 \mathrm{E}-03$ & $1.85 \mathrm{E}-02$ & $3.17 \mathrm{E}-02$ & $1.97 \mathrm{E}-02$ & $3.54 \mathrm{E}-02$ \\
\hline $\mathrm{Cr}$ & wet & $2.00 \mathrm{E}-03$ & 3 & 0.075 & $1.20 \mathrm{E}-03$ & $3.82 \mathrm{E}-03$ & $1.89 \mathrm{E}-02$ & $3.23 \mathrm{E}-02$ & $2.01 \mathrm{E}-02$ & $3.61 \mathrm{E}-02$ \\
\hline $\mathrm{Mn}$ & dry & $1.00 \mathrm{E}-03$ & 24 & 0.96 & $3.98 \mathrm{E}-02$ & $1.27 \mathrm{E}-01$ & $4.89 \mathrm{E}-03$ & $8.36 \mathrm{E}-03$ & $4.47 \mathrm{E}-02$ & $1.35 \mathrm{E}-01$ \\
\hline Mn & wet & $1.00 \mathrm{E}-03$ & 24 & 0.96 & $2.16 \mathrm{E}-02$ & $6.86 \mathrm{E}-02$ & $2.65 \mathrm{E}-03$ & $4.53 \mathrm{E}-03$ & $2.42 \mathrm{E}-02$ & $7.32 \mathrm{E}-02$ \\
\hline $\mathrm{Fe}$ & dry & $1.00 \mathrm{E}-03$ & 700 & 140 & $1.45 \mathrm{E}-02$ & $4.60 \mathrm{E}-02$ & $3.55 \mathrm{E}-04$ & $6.08 \mathrm{E}-04$ & $1.48 \mathrm{E}-02$ & 4.67E-02 \\
\hline $\mathrm{Fe}$ & wet & $1.00 \mathrm{E}-03$ & 700 & 140 & 4.57E-03 & $1.45 \mathrm{E}-02$ & $1.12 \mathrm{E}-04$ & $1.92 \mathrm{E}-04$ & $4.68 \mathrm{E}-03$ & $1.47 \mathrm{E}-02$ \\
\hline Co & dry & 4.00E-04 & 0.3 & 0.06 & $2.35 \mathrm{E}-02$ & 7.47E-02 & $2.30 \mathrm{E}-04$ & $3.94 \mathrm{E}-04$ & $2.37 \mathrm{E}-02$ & $7.51 \mathrm{E}-02$ \\
\hline Co & wet & 4.00E-04 & 0.3 & 0.06 & $8.44 \mathrm{E}-03$ & $2.68 \mathrm{E}-02$ & $8.28 \mathrm{E}-05$ & $1.42 \mathrm{E}-04$ & $8.52 \mathrm{E}-03$ & $2.70 \mathrm{E}-02$ \\
\hline $\mathrm{Ni}$ & dry & $2.00 \mathrm{E}-04$ & 20 & 0.8 & $1.32 \mathrm{E}-04$ & $4.21 \mathrm{E}-04$ & $8.12 \mathrm{E}-05$ & $1.39 \mathrm{E}-04$ & 2.14E-04 & $5.60 \mathrm{E}-04$ \\
\hline $\mathrm{Ni}$ & wet & $2.00 \mathrm{E}-04$ & 20 & 0.8 & $8.22 \mathrm{E}-05$ & 2.62E-04 & $5.04 \mathrm{E}-05$ & 8.63E-05 & $1.33 \mathrm{E}-04$ & $3.48 \mathrm{E}-04$ \\
\hline $\mathrm{Cu}$ & dry & $1.00 \mathrm{E}-03$ & 40 & 8 & $1.77 \mathrm{E}-03$ & $5.63 \mathrm{E}-03$ & 7.61E-05 & $1.30 \mathrm{E}-04$ & $1.84 \mathrm{E}-03$ & $5.76 \mathrm{E}-03$ \\
\hline $\mathrm{Cu}$ & wet & $1.00 \mathrm{E}-03$ & 40 & 8 & $8.53 \mathrm{E}-04$ & $2.71 \mathrm{E}-03$ & $3.67 \mathrm{E}-05$ & $6.28 \mathrm{E}-05$ & $8.90 \mathrm{E}-04$ & $2.78 \mathrm{E}-03$ \\
\hline $\mathrm{Zn}$ & dry & $6.00 \mathrm{E}-04$ & 300 & 60 & $1.63 \mathrm{E}-04$ & $5.19 \mathrm{E}-04$ & $1.20 \mathrm{E}-05$ & 2.06E-05 & $1.75 \mathrm{E}-04$ & $5.40 \mathrm{E}-04$ \\
\hline $\mathrm{Zn}$ & wet & $6.00 \mathrm{E}-04$ & 300 & 60 & $1.43 \mathrm{E}-04$ & 4.54E-04 & $1.05 \mathrm{E}-05$ & $1.80 \mathrm{E}-05$ & $1.53 \mathrm{E}-04$ & 4.72E-04 \\
\hline As & dry & $1.00 \mathrm{E}-03$ & 0.3 & 0.285 & $7.86 \mathrm{E}-01$ & $2.50 \mathrm{E}+00$ & $4.28 \mathrm{E}-03$ & 7.32E-03 & $7.91 \mathrm{E}-01$ & $2.51 \mathrm{E}+00$ \\
\hline As & wet & $1.00 \mathrm{E}-03$ & 0.3 & 0.285 & 2.85E-01 & 9.07E-01 & $1.55 \mathrm{E}-03$ & $2.65 \mathrm{E}-03$ & $2.87 \mathrm{E}-01$ & $9.09 \mathrm{E}-01$ \\
\hline Mo & dry & $1.00 \mathrm{E}-03$ & 5 & 1.9 & $2.24 \mathrm{E}-02$ & 7.13E-02 & $2.89 \mathrm{E}-04$ & 4.95E-04 & $2.27 \mathrm{E}-02$ & $7.18 \mathrm{E}-02$ \\
\hline Mo & wet & $1.00 \mathrm{E}-03$ & 5 & 1.9 & $1.19 \mathrm{E}-02$ & $3.78 \mathrm{E}-02$ & $1.53 \mathrm{E}-04$ & 2.62E-04 & $1.20 \mathrm{E}-02$ & $3.80 \mathrm{E}-02$ \\
\hline $\mathrm{Cd}$ & dry & $1.00 \mathrm{E}-03$ & 0.5 & 0.025 & 8.49E-04 & $2.70 \mathrm{E}-03$ & $1.67 \mathrm{E}-03$ & $2.85 \mathrm{E}-03$ & $2.52 \mathrm{E}-03$ & $5.55 \mathrm{E}-03$ \\
\hline $\mathrm{Cd}$ & wet & $1.00 \mathrm{E}-03$ & 0.5 & 0.025 & $4.06 \mathrm{E}-04$ & $1.29 \mathrm{E}-03$ & $7.96 \mathrm{E}-04$ & $1.36 \mathrm{E}-03$ & $1.20 \mathrm{E}-03$ & $2.65 \mathrm{E}-03$ \\
\hline $\mathrm{Sb}$ & dry & $1.00 \mathrm{E}-03$ & 0.4 & 0.06 & 3.13E-03 & $9.97 \mathrm{E}-03$ & $6.84 \mathrm{E}-04$ & $1.17 \mathrm{E}-03$ & $3.82 \mathrm{E}-03$ & $1.11 \mathrm{E}-02$ \\
\hline $\mathrm{Sb}$ & wet & $1.00 \mathrm{E}-03$ & 0.4 & 0.06 & $3.14 \mathrm{E}-03$ & $9.98 \mathrm{E}-03$ & $6.84 \mathrm{E}-04$ & $1.17 \mathrm{E}-03$ & $3.82 \mathrm{E}-03$ & $1.11 \mathrm{E}-02$ \\
\hline $\mathrm{Tl}$ & dry & $1.00 \mathrm{E}-03$ & 0.01 & 0.01 & $1.42 \mathrm{E}-01$ & $4.51 \mathrm{E}-01$ & $6.96 \mathrm{E}-04$ & $1.19 \mathrm{E}-03$ & $1.42 \mathrm{E}-01$ & $4.52 \mathrm{E}-01$ \\
\hline $\mathrm{Tl}$ & wet & $1.00 \mathrm{E}-03$ & 0.01 & 0.01 & $1.28 \mathrm{E}-01$ & 4.07E-01 & $6.28 \mathrm{E}-04$ & $1.07 \mathrm{E}-03$ & $1.28 \mathrm{E}-01$ & $4.08 \mathrm{E}-01$ \\
\hline $\mathrm{Pb}$ & dry & $1.00 \mathrm{E}-04$ & 1.4 & 0.42 & $6.37 \mathrm{E}-03$ & $2.03 \mathrm{E}-02$ & $3.48 \mathrm{E}-05$ & $5.95 \mathrm{E}-05$ & $6.41 \mathrm{E}-03$ & $2.03 \mathrm{E}-02$ \\
\hline $\mathrm{Pb}$ & wet & $1.00 \mathrm{E}-04$ & 1.4 & 0.42 & $4.35 \mathrm{E}-03$ & $1.38 \mathrm{E}-02$ & $2.37 \mathrm{E}-05$ & $4.06 \mathrm{E}-05$ & 4.38E-03 & $1.39 \mathrm{E}-02$ \\
\hline $\mathrm{U}$ & dry & $1.00 \mathrm{E}-03$ & - & - & & & & & & \\
\hline $\mathrm{U}$ & wet & $1.00 \mathrm{E}-03$ & - & - & & & & & & \\
\hline
\end{tabular}


Table S2. Carcinogenic risk results of $\mathrm{Cr}$, $\mathrm{As}$ and $\mathrm{Pb}$ in Ganjiang River basin.

\begin{tabular}{|c|c|c|c|c|c|c|c|c|c|c|}
\hline \multirow{2}{*}{ Element } & \multirow{2}{*}{ Season } & \multirow{2}{*}{$\mathrm{ABS}_{\mathrm{GI}}$} & \multirow{2}{*}{ CSFingestion } & \multirow{2}{*}{ CSFdermal } & \multicolumn{2}{|c|}{ CRingestion } & \multicolumn{2}{|c|}{ CRdermal } & \multicolumn{2}{c|}{ CRtotal } \\
\cline { 8 - 12 } & & & & & & & & & & \\
$\mathrm{Cr}$ & dry & 0.025 & $5.00 \mathrm{E}-01$ & $2.00 \mathrm{E}+01$ & $1.77 \mathrm{E}-06$ & $5.63 \mathrm{E}-06$ & $2.78 \mathrm{E}-05$ & $4.75 \mathrm{E}-05$ & $2.95 \mathrm{E}-05$ & $5.32 \mathrm{E}-05$ \\
\hline $\mathrm{Cr}$ & wet & 0.025 & $5.00 \mathrm{E}-01$ & $2.00 \mathrm{E}+01$ & $1.80 \mathrm{E}-06$ & $5.73 \mathrm{E}-06$ & $2.83 \mathrm{E}-05$ & $4.84 \mathrm{E}-05$ & $3.01 \mathrm{E}-05$ & $5.41 \mathrm{E}-05$ \\
\hline $\mathrm{As}$ & dry & 0.95 & $1.50 \mathrm{E}+00$ & $1.58 \mathrm{E}+00$ & $\mathbf{3 . 5 4 E - 0 4}$ & $1.13 \mathrm{E}-03$ & $1.92 \mathrm{E}-06$ & $3.29 \mathrm{E}-06$ & $3.56 \mathrm{E}-04$ & $1.13 \mathrm{E}-03$ \\
\hline $\mathrm{As}$ & wet & 0.95 & $1.50 \mathrm{E}+00$ & $1.58 \mathrm{E}+00$ & $\mathbf{1 . 2 8 E}-04$ & $4.08 \mathrm{E}-04$ & $6.98 \mathrm{E}-07$ & $1.19 \mathrm{E}-06$ & $1.29 \mathrm{E}-04$ & $4.09 \mathrm{E}-04$ \\
\hline $\mathrm{Pb}$ & dry & 0.3 & $8.50 \mathrm{E}-03$ & $2.83 \mathrm{E}-02$ & $7.58 \mathrm{E}-08$ & $2.41 \mathrm{E}-07$ & $4.14 \mathrm{E}-10$ & $7.08 \mathrm{E}-10$ & $7.63 \mathrm{E}-08$ & $2.42 \mathrm{E}-07$ \\
\hline $\mathrm{Pb}$ & wet & 0.3 & $8.50 \mathrm{E}-03$ & $2.83 \mathrm{E}-02$ & $5.18 \mathrm{E}-08$ & $1.65 \mathrm{E}-07$ & $2.83 \mathrm{E}-10$ & $4.83 \mathrm{E}-10$ & $5.21 \mathrm{E}-08$ & $1.65 \mathrm{E}-07$ \\
\hline
\end{tabular}

